\title{
A Influência da Filosofia Escolástica na Formação do Pensamento Econômico
}

\author{
The Influence Of Scholastic Philosophy on the Formation of Economic Thought \\ La Influencia de La Filosofía Escolástica en la Formación del Pensamiento Económico
}

Gabriel Estruzani Queiróz de Melo*

Palavras-chave:

Escolástica,

Pensamento,

Econômico,

Universidade de

Salamanca,

Mercado,

Usura.

\section{Keywords:}

Scholastic Philosophy,

Economic Thought,

University of Salamanca,

Market,

Usury.

\section{Palabras clave:}

Escolástica,

Pensamiento Económico,

Universidad de

Salamanca,

Mercado,

Usura.
Resumo: O presente estudo buscou avaliar o papel que a escola de filosofia escolástica, tanto no seu apogeu quanto na fase tardia, teve para a formação de fundamentais conceitos que formam a base de qualquer pensamento econômico ulterior. Foram apresentadas considerações escolásticas acerca de auto regulação do mercado, comércio, preço justo, teoria do valor, concorrência, propriedade, inflação e valor do dinheiro no tempo. A universidade de Salamanca mereceu destaque, tanto por ser o berço das teorias da economia de mercado, quanto por tentar conciliar as ideias econômicas com as bases morais e históricas, de matriz judaico-cristãs, que sempre nortearam os pensadores escolásticos. Através de uma pesquisa bibliográfica e histórica, com base documental, tanto de fontes primárias quanto de estudos posteriores, o presenta trabalho mostra as raízes escolásticas de escolas de pensamento econômico contemporâneas e a indissociabilidade dos conceitos por elas utilizados de seus autores originais.

Abstract: The present study analysis the influence that scholastic philosophy had on the formation of fundamental concepts in economic thought. It shows scholastic considerations on market self-regulation, trade, fair price, value theory, competition, property, inflation and the value of money. The University of Salamanca deserves prominence both because it was the cradle of free market economic theories and because it tried to reconcile economic ideas with the moral and historical bases of Judeo-Christian matrix, which always guided the scholastic thinkers. Through bibliographical and historical research, both of primary sources and of later studies, the present work shows the scholastic roots of contemporary economic schools of thought and the relationship between the concepts they use and their original authors.

Resumen: El presente estudio buscó evaluar el papel que la escuela de filosofía escolástica, tanto en su apogeo como en la fase tardía, tuvo en la formación de conceptos fundamentales que forman la base de cualquier pensamiento económico ulterior. Se presentaron consideraciones escolásticas acerca de la regulación del mercado, el comercio, el precio justo, la teoría del valor, la competición, la propiedad, la inflación y el valor del dinero en eltiempo. La universidad de Salamanca mereció destaque, tanto por ser la cuna de las teorías de la economía de mercado como por tratar de conciliar las ideas económicas con las bases morales e históricas, de matriz judeo-cristiana, que siempre guiaron a los pensadores escolásticos. A través de una investigación bibliográfica y histórica, con base documental, tanto de fuentes primarias y de estudios posteriores, el presente estudio muestra las raíces escolásticas de escuelas de pensamiento económico contemporáneas y la indisociación de los conceptos por ellas utilizados de sus autores originales.

\footnotetext{
* Graduado em Ciências Econômicas e Mestrando em Administração pela UDESC. Pesquisador na área de Economia Institucional. Interessa-se por Filosofia da Economia e História das Ideias Econômicas. Email: gabrieldemelo51@gmail.com
} 


\section{Introdução}

É necessário repensar os conceitos já estabelecidos em relação à Idade Média, visto que, ainda hoje, circula a errônea ideia de que foi um período de ignorância, superstição e repressão intelectual. Porém, segundo Schumpeter (1954, p. 74),

[...] as universidades gozavam de uma grande liberdade e independência; elas deram mais escopo ao professor individual do que as universidades mecanizadas de hoje; eram um ponto de encontro de todas as classes da sociedade; e elas eram essencialmente internacionais.

Segundo Woods Jr. (2005, p. 65),

[...] De fato, entre as contribuições medievais mais importantes para a ciências moderna estava a investigação essencialmente livre do sistema universitário, onde os estudiosos poderiam debater e discutir preposições, e na qual a utilidade da razão humana era tomada como garantia. Ao contrário do quadro grosseiramente impreciso da Idade Média que hoje passa pelo conhecimento comum, a vida intelectual medieval deu contribuições indispensáveis à civilização ocidental.

Os escolásticos, a despeito do que se pode imaginar devido a sua formação religiosa, não estavam preocupados apenas com questões teológicas, eles atuaram nas áreas da filosofia e teoria do conhecimento. Juntamente com a filosofia e a teologia, os escolásticos obtiveram grande sucesso no desenvolvimento das áreas de gramática, retórica, direito civil e canônico, navegação e medicina (GRICE-HUTCHINSON, 1952; SCHUMPETER, 1954).

A maior parte dos historiadores da economia afirma que a ciência econômica nasceu no século XVIII com Adam Smith e os pensadores concomitantes a ele. Na contramão destes, existem historiadores e comentaristas da escolástica que argumentam que os filósofos dessa corrente foram os primeiros a desenvolver a ideia de um mercado que se autorregulava (WOODS JR, 2005).

Tanto os escolásticos tardios quanto os anteriores são pedra angular na formulação de conceitos que são comuns e necessários para o estudo das mais importantes correntes econômicas, ao ponto de Schumpeter $(\underline{1954}$, p. 93$)$ afirmar que “[...] São eles que chegam mais perto do que qualquer outro grupo de serem os fundadores da economia cientifica". Nos escolásticos se encontram importantes reflexões sobre comércio, intercâmbio e preço justo, além disso, também encontramos em seus escritos as raízes da teoria subjetiva do valor (SÀNCHEZ-SERNA; ARIAS BELLO, 2012).

Além de se destacarem por fundar a teoria das expectativas, a teoria do valor subjetivo e de escreverem os primeiros tratados sobre a moeda, os escolásticos medievais ainda contribuíram, em menor escala, com outros princípios econômicos cruciais para o desenvolvimento desta ciência (WOODS JR., 2005).

Defenderam princípios de liberdade econômica e mercados desregulados, contribuíram para os estudos referentes a preços e salários e anteciparam teorias econômicas, que só foram formalizadas mais tarde. Compreenderam bem os fenômenos do capitalismo nascente e, por isso, serviram como base do trabalho analítico de seus sucessores, incluindo Adam Smith (CHAFUEN, 2003; SCHUMPETER, 1954). 
É importante dizer que, apesar de terem tamanha importância para a formação do pensamento econômico, nunca foi o objetivo dos doutores escolásticos criar uma nova ciência, estes estavam muito mais preocupados com questões de cunho moral, todavia, tendo em vista o fato de que as interações econômicas são inerentes à convivência humana, era necessário fazer deliberações sobre elas. Porém, existia uma faculdade de teologia dedicada especialmente a assuntos de interesse econômico, a Universidade de Salamanca. Fundada pelo monarca dos reinos de Leão e Galícia, Alfonso IX de León, no ano de 1218. Dentro desta universidade, no século XV, nasceu a escola de pensamento filosófico, chamada de Escola de Salamanca, fundada pelo padre Dominicano e teólogo escolástico Francisco de Vitória, onde se usava da base intelectual deixada de legado por seus antecessores escolásticos para defender a teoria do valor subjetivista, o livre comércio e o direito à propriedade privada (FABRE, 1998).

É necessário desmistificar a falsa ideia de que o medievo seria uma época obscurantista e intelectualmente repressiva, de pouco desenvolvimento científico e filosófico, pensamento este que, infelizmente, segue dominante em grande parte dos ciclos acadêmicos e instituições educacionais, quando na verdade foi um tempo de desenvolvimento político, social, tecnológico e científico (HUIZINGA, 1978). Ao comentar sobre a evolução do pensamento filosófico do século XII, Le Goff (2003, p. 78) aponta que "Assim prossegue essa obra de dessacralização da natureza, de crítica do simbolismo, prolegômenos necessários a qualquer ciência [...]".

\section{Desenvolvimento}

\subsection{O pensamento econômico}

As interações econômicas são intrínsecas à existência da vida em sociedade, uma vez que sempre foi necessário, em alguns momentos da história humana mais do que em outros, manejar recursos escassos. Além disso, as pessoas sempre conviveram com situações de compra e venda destes mesmos recursos, em relações mercantis, onde definir o valor deles era fundamental para que cada um, pensando em seu interesse individual, maximiza-se sua utilidade. Apesar de tão familiar a todas as sociedades, a economia ainda é uma das ciências mais jovens conhecidas, tornando difícil oferecer uma definição exata.

Segundo Mankiw $(2012$, p. 10) “Economia é o estudo de como os seres humanos tomam decisões em face da escassez. Estas podem ser decisões individuais, decisões familiares, decisões de negócios ou decisões sociais". Apresentando um conceito mais amplo, Garcia e Vasconcellos (2004, p. 2) definem economia como:

[...] a ciência social que estuda como o indivíduo e a sociedade decidem (escolhem) empregar recursos produtivos escassos na produção de bens e serviços, de modo a distribuí-los entre as várias pessoas e grupos da sociedade, a fim de satisfazer as necessidades humanas.

\subsubsection{A Influência da Filosofia Escolástica na Formação do Pensamento Econômico}

O economista teórico Ludwig Von Mises (2010, p. 325), entretanto, define economia de forma mais abstrata e filosófica do que propriamente técnica, defendendo que "A economia [...] é a teoria de toda ação humana, a ciência geral das imutáveis categorias da ação e do seu funcionamento em quaisquer condições imagináveis sob as quais o homem age". 
A economia, tanto em seu aspecto filosófico, como em seu aspecto prático, não pode ser definida como ciência da mesma maneira que a matemática ou a física o são, demandando total rigor, exatidão e objetividade. Apesar de se utilizar de um instrumental matemático muito consistente e conter considerável dose de empirismo, ela deve ser analisada do ponto de vista das ciências sociais, não das exatas. Na análise do pensamento econômico, sempre deve ser dada a devida atenção para componentes históricos, sociológicos, morais e até mesmo religiosos, que permearam os meios onde ele se desenvolveu (SCHUMPETER, 1954).

Antes mesmo do termo ciência econômica, ainda no século XVII, era utilizado o termo "economia política", que se propunha a analisar os aspectos relacionados aos ciclos de produção e comercialização de bens elementares aos homens. Esta abordagem manteve-se inalterada até as publicações de Adam Smith. Ela tratava da natureza da riqueza e da produção, de forma teórica, sem se preocupar com questões empíricas, era, por assim dizer, o estudo dos esforços humanos para suprir suas necessidades, medidas em termos de riqueza. O termo "economia política" começou a ser suprimido a partir do surgimento dos economistas marginalistas, como Jevons e Menger, e foi efetivamente abandonado com os neoclássicos como Alfred Marshall e Irving Fisher. Ambas as escolas entendiam o estudo da economia como um conhecimento objetivo e científico, dependente de seus instrumentos matemáticos (GENNARI; OLIVEIRA, 2009; MENGER, 2017).

Segundo Robbins (1932, p. 15)

O economista estuda a alocação de meios escassos. Ele se interessa pelo modo como os diferentes graus de escassez de bens distintos fazem surgir diferentes relações de valoração entre eles, e se interessa pelo modo como as mudanças nas condições de escassez, sejam elas trazidas por mudança nos fins ou nos meios - pelo lado da demanda ou da oferta - afetam essas relações. A Economia é a ciência que estuda o comportamento humano como uma relação entre fins e meios escassos que têm usos alternativos.

No século XVIII, quando o estudo do que viria a se chamar de ciência econômica, começa a tomar proporções inéditas, existem duas linhas de pensamento principais que tentavam a definir, a materialista (ou do bem-estar), apoiada em sua maioria pelos teóricos anglo-saxões e herdeira da fisiocracia, e a sua opositora, que defendia o conceito da escassez.

O conceito do bem-estar tenta medir o progresso econômico pela utilidade criada pelos processos produtivos, mas essa definição não se sustenta, uma vez que o estudo da economia leva em conta tanto os preços de produtos que tem utilidade prática, quanto os que têm apenas utilidade subjetiva. Já o conceito da escassez diz que o indivíduo toma decisões de modo a economizar recursos em algumas atividades para poder empregar em outras, assim definindo o preço das coisas, baseado na quantidade em que elas existem e no quanto são desejadas (ROBBINS, 1932).

Exatamente por ter uma definição tão aberta e subjetiva, existe, ainda hoje, entre os historiadores da Economia, o debate sobre quando a ciência teve sua gênese. A corrente principal defende que foi com Adam Smith, no século XVIII, com sua obra "Uma Investigação sobre a Natureza e as Causas da Riqueza das Nações" (ou ainda com sua obra anterior: "Teoria dos sentimentos morais"). 
Ainda existe um segundo grupo que defende que a ciência econômica teve seu início com a teoria fisiocrata, representada principalmente por François Quesnay e Anne Robert Jacques Turgot, os quais afirmavam que a riqueza das nações derivava das terras cultiváveis. Estes, na sua maioria franceses, se denominavam les economistes, entendiam que a produção de um país era equivalente a seus recursos agrícolas e que o modo como o homem transformava a natureza era mais importante para o desenvolvimento econômico do que sua relação com seus pares (

Segundo Marx (1974, p. 26):

Corresponde aos fisiocratas a honra de ter analisado o capital na sociedade moderna. Isto lhes dá o direito de se considerarem como os verdadeiros fundadores da moderna economia. Foram os primeiros que analisaram os diversos elementos materiais em que o capital existe e se manifesta durante o processo de trabalho. [...] está claro que eles não podiam deixar de ver, nas formas burguesas de produção, formas naturais, mas tiveram o grande acerto de conceber essas mesmas formas como formas fisiológicas da sociedade, impostas pela necessidade natural da produção ou independentes da política, da vontade etc. Trata-se de leis materiais.

William Petty (1623-1687), famoso por sua proposição de métodos quantitativos para estudo das riquezas nacionais, defendia que existem dois tipos de renda: a da terra e a dos juros. A da terra é simplesmente o valor total da colheita, subtraída dos gastos com insumos e trabalhadores. A agricultura tinha uma utilidade especial para Petty, pois era a única atividade capaz de gerar excedente para o trabalhador. Por outro lado, a renda do juro correspondia ao pagamento pelo risco que corria o investidor, ao abrir mão de moeda, que representava riqueza líquida e certa, para aplicá-la em uma atividade onde não havia nenhuma garantia de retorno, por melhor que fossem as perspectivas. Foram nessas ideias de Petty que os fisiocratas defenderam que, somente o trabalho produtivo é capaz de gerar um produto líquido, em especial a agricultura, em face da renda com juros, do trabalho com comércio ou com manufaturas. Estes seriam trabalhos estéreis, que apenas transferem riqueza, mas não a criam.

Outro autor que influenciou os pensamentos fisiocrata e clássico foi Richard Cantillon, que causou uma revolução no estudo da ciência econômica ao publicar, no ano de 1755 sua obra Sobre a natureza do comércio em geral, que continha percepções sobre valor e preço, oferta e demanda e autorregulação do mercado, antecipando, em pelo menos 20 anos, Adam Smith. Este tratado, escrito cerca de 25 anos antes de sua efetiva publicação, foi o primeiro a apresentar bases organizacionais e científicas para o estudo da economia (FEIJÓ, 2001; IORIO, 2017).

Thorton (2006) considera que Cantillon foi o primeiro economista a analisar com sucesso a natureza cíclica da economia capitalista, desenvolvendo o que chamamos hoje de modelo de fluxo circular da riqueza. Cantillon considerava que o dinheiro e os juros tinham uma natureza autorregulatória, tendendo sempre ao equilíbrio e só podiam ser perturbadas por manipulações bancárias ou intervenções monetárias por parte do governo. Ele atacou, por isso, toda a noção de controle governamental da oferta monetária. Assim como Von Mises, defendeu que qualquer quantidade de dinheiro é suficiente para o bom funcionamento da economia, já que o que os indivíduos buscam não é grandeza dos meios de pagamento, mas sim poder de compra. 
Murray Rothbard (1995) inclusive considera Cantillon como o fundador da ciência econômica ao usar o que chama de "praxiologia", que é uma espécie de estudo econômico baseado em axiomas amplos e auto evidentes, deduzidos logicamente, sem necessidade de empirismo. Essa metodologia praxiológica o permitiu descobrir relações naturais de causa e efeito na economia de mercado. Justamente essa não necessidade de empirismo permitiu a Cantillon isolar o fenômeno econômico, utilizando-se de abstração ou de construção imaginária, para confeccionar modelos simples, e aceitando que existem variáveis incontroláveis (ou exógenas) a eles e com o benefício do preceito ceteris paribus (IORIO, 2017).

Além das contribuições metodológicas e sobre a natureza do dinheiro que Cantillon fez, outra marca importante foi deixada: sua visão evolucionária sobre o papel do empreendedor. O empreendedor é aquele que toma riscos e gastos certos para, talvez, colher frutos que são incertos, seja esse um empreendedor, um produtor ou um comerciante. Por isso, o empreendedor deveria receber mais do que apenas o valor do produto final, era a recompensa que ele recebia por assumir riscos. Os empresários estavam vinculados em reciprocidade com os seus clientes, uma vez que, para vender seus produtos, eram clientes de outros empresários, ou seja, a demanda por produtos é o que define o número de empresários em uma economia. Essa definição, apesar de inovadora, é uma claramente derivada da escolástica. O padre Luís de Molina já havia enunciado uma definição neste sentido, porém muito menos rebuscada, em torno de um século e meio antes (IORIO, 2017; SCHUMPETER, 1954).

Um grupo minoritário, porém, muito influente, constituído basicamente por pensadores da escola Austríaca de economia, defende que a ciência econômica nasceu, de forma difusa e desordenada, com os filósofos da escolástica, especialmente os escolásticos tardios da universidade Salamanca, como Friedrich Hayek, que argumentou, ainda nos anos 1970, que as bases da economia de mercado, e em especial do laissez-faire, não são resultado das obras de escritores anglo-saxões protestantes, como linhas mais tradicionais da literatura, em especial Max Weber em uma das suas mais importantes obras: A ética protestante e o espírito do capitalismo, tendem a defender, mas sim de padres das ordens franciscanas, esuítas e dominicanas Espanholas, apesar de ser importante destacar que pensadores de outras escolas posteriores ao final do escolasticismo, como os fisiocratas, também tiveram contribuições originais e indispensáveis antes do surgimento da economia clássica (IORIO, 2017).

\section{$1.2 \mathrm{O}$ pensamento no mundo antigo}

A despeito dos méritos contidos nas defesas de cada corrente sobre o início da ciência econômica, é seguro afirmar que o pensamento econômico é bastante anterior e remonta ao período pré-helenístico, encontrado inclusive em fragmentos de Tales de Mileto e Xenofonte. Segundo Oliveira e Gennari (2009, p. 7) "A palavra "economia" vem do grego oikonomikos. O termo resulta da composição da palavra oikos (que significa casa ou unidade doméstica) com o radical semântico nem (que significa regulamentar, administrar, organizar)".

Rothbard (1995, p. 8) segue a mesma linha de raciocínio ao afirmar que "no decorrer do pioneirismo filosófico, seu filosofar sobre o homem e seu mundo produziu fragmentos de pensamentos e ideias político-econômicas ou mesmo estritamente econômicas". Porém, ele faz um alerta para evitar o erro do anacronismo, segundo ele "ninguém deve ser enganado ao pensar que os antigos gregos eram "economistas" no sentido moderno". E conclui: 
É verdade que o termo "economia" é grego, proveniente da oikonomia grega, mas oikonomia significa não economia em nosso sentido, mas "gestão doméstica", e os tratados sobre "economia" discutiriam o que poderia ser chamado de tecnologia de gestão familiar - útil talvez, mas certamente não o que consideramos hoje como economia.

O alerta de Rothbard é extremamente válido, sendo necessário também deixar claro que os primeiros filósofos pós-socráticos a abordarem temas de interesse econômico, não estavam preocupados com questões como preços, inflação ou desemprego. Seu interesse partia da perspectiva ética e do funcionamento da pólis.

Durante a era de ouro da filosofia grega, Atenas experimentava condições sócio-políticoeconômicas que permitiram reflexões relevantes para o desenvolvimento de qualquer pensamento econômico, como a ampliação do comércio e da liberdade de trocas entre as cidades-Estados da região (ANTISERI; REALE, 2003).

O desenvolvimento econômico da época permitiu que a produção passasse a ser mais sofisticada, exigindo especialização dos trabalhadores, segundo Oliveira e Gennari (2009, p. 8)

Essa "especialização" fez com que o homem passasse a depender dos demais para obter os artigos de que necessitava, mas não produzia. Assim surgiu a necessidade de cooperação, e a pólis é o ambiente no qual os homens cooperam entre si para produzir e obter, por meio da troca, os produtos de que necessitam para viver melhor.

Para Aristóteles, as dinâmicas sociais e de produção se davam no sentido de proporcionar a sobrevivência do indivíduo e de se sua família. Ele transforma a natureza e se relaciona com outros homens para garantir isso. Aristóteles divide estas dinâmicas em duas categorias: aquisição natural (também chamada de economia) e aquisição artificial (também chamada de crematística). A primeira faz referência à produção em seu sentido estrito, a capacidade de transformar a natureza para criar um instrumento, de domesticar um animal para desfrutá-lo ou mesmo de coletar alimentos, já a segunda é a acumulação especulativa, onde a acumulação de riqueza é um fim por si só, não se pretende criar nada com ela, é o caso, por exemplo, do comércio (GENNARI; OLIVEIRA, 2009).

Este pensamento de Aristóteles, de condenar o comércio como força meramente especulativa, muito se relaciona com o seu mentor Platão, que acreditava que a função da atividade econômica deveria ser promover o bem-estar e o desenvolvimento da pólis, os bens e riquezas deveriam ser propriedade da pólis e não do indivíduo (ROTHBARD, 1995).

Confirmando a prioridade que ambos davam à pólis em detrimento do indivíduo, Oliveira e Gennari (2009, p. 7-8) afirmam que:

Tanto Platão quanto Aristóteles orientaram a atenção para a vida econômica com o objetivo de extrair normas práticas que garantissem condições de vida adequadas aos cidadãos, o funcionamento, a harmonia e a estabilidade política da pólis. Da perspectiva que eles assumiam, o homem era entendido como um conjunto de potencialidades integradas (físicas, produtivas, éticas, artísticas, intelectuais e espirituais) cuja realização plena só seria possível na vida em sociedade, isto é, no interior da pólis.

Segundo Joner (2015, p. 17) 
Aristóteles compreendia que a felicidade do Estado era a mesma felicidade dos particulares, portanto não poderia haver felicidade de particulares sem que houvesse a felicidade da pólis como um todo, afirmando que o melhor governo é aquele que encontra a melhor maneira de viver feliz.

Platão contribui com noções que mais tarde seriam chamadas de divisão social do trabalho, mas era inegavelmente hostil em relação ao mercado. Na contramão de ambos, os sofistas eram aprazíveis ao mercado e receavam interferências do governo nele (GENNARI; OLIVEIRA, 2009; SCHUMPETER, 1954).

É fácil entender o porquê de os primeiros insights econômicos terem se revelado na Grécia antiga, segundo Schumpeter (1954, p. 51) "O pensamento grego, mesmo quando mais abstrato, sempre girava em torno dos problemas concretos da vida humana". E completa "[...] o filósofo grego era essencialmente um filósofo político: era da pólis que ele olhava para o universo, e era o universo - tanto do pensamento como de todas as outras preocupações humanas que ele encontrou refletido na pólis".

Apesar do evidente destaque que estes receberam, não é correto imaginar que o pensamento econômico no mundo antigo se resumiu aos pensadores gregos. Os pensadores romanos prémedievais também tiveram sua importante contribuição. Assim como os gregos, os romanos não estavam exatamente preocupados em resolver problemas puramente econômicos, seus esforços eram dirigidos para resolver questões centrais do dia a dia da comunidade, que, por vezes, esbarravam em assuntos da esfera econômica.

Um dos grandes legados que a civilização Romana deixou para posteridade foi o seu direito, e é justamente em seus códigos de leis que se encontra a maior parte da contribuição ao pensamento econômico que eles têm a apresentar.

Os juristas romanos, segundo Schumpeter (1954, p. 66) “[...] criaram uma lógica jurídica que provou ser aplicável a uma grande variedade de padrões sociais - de fato a qualquer padrão social que reconheça a propriedade privada e o comércio capitalista". E completa: "na medida em que seus fatos eram econômicos, sua análise era análise econômica”.

Segundo Rothbard (1995, p. 31) "os direitos de propriedade privada e o laissez-faire eram, portanto, a herança fundamental da lei romana até os séculos seguintes, e grande parte disso foi adotada pelos países do Ocidente cristão". O direito Romano permitia pouca influência do Estado sobre a vida pessoal do indivíduo, inclusive nos assuntos que tangiam a vida econômica do mesmo, em raríssimas vezes arbitrava sobre o preço dos produtos ou alocação dos recursos privados disponíveis.

Nesta linha de raciocínio, Rothbard completa:

[...] O preço "justo" (justum pretium) era simplesmente qualquer preço alcançado por negociação gratuita e voluntária entre comprador e vendedor. Cada homem tem o direito de fazer o que quer com sua propriedade e, portanto, tem o direito de fazer contratos para distribuir, comprar ou vender esses bens; portanto, qualquer preço livremente chegado é "justo".

A cultura jurídica ocidental, especialmente nos países latinos, foi formada em grande parte pelo direito Romano, em especial no que diz respeito ao direito privado. $\mathrm{O}$ direito privado Romano considerava a existência de um direito subjetivo da propriedade, que era inerente 
à natureza humana, já que o acúmulo de capital é próprio dela (BARBOSA; PAMPLONA FILHO, 2004).

A grande revolução jurídica Romana, no tocante à propriedade privada, consiste nos bens imóveis. Sociedades mais antigas só consideravam a existência de propriedade para os bens móveis, tais quais, objetos de trabalho ou de uso pessoal. As terras pertenciam à coletividade, ou ao Estado. Essa mesma propriedade era considerada absoluta, individual, ilimitada e perpétua, tendo sua transmissão garantida para seus sucessores (DEBONI, 2011; VENOSA, 1999).

\subsection{Os Escolásticos}

É chamada de escolástica, a corrente de filosofia medieval que tentava harmonizar a filosofia grega e a fé Judaico-Cristã mediante a recuperação e interpretação dos escritos clássicos do pensamento Platônico, Neoplatônico e Aristotélico. De forma mais simples, pode-se dizer que são os homens da ciência no medievo. Era chamada de escolástica, também, o método universitário aplicado em universidades medievais, caso de Bologna, Oxford e Salamanca (LE GOFF, 2003; SÁNCHEZ-SERNA; ARIAS BELLO, 2012; SCHUMPETER, 1954).

O termo "escolástica" vem do latim scholasticus, e faz referência ao professor das artes liberais (trivio e quadrívio) e de teologia ou filosofia que, à época, não raras vezes confundiam- se em um só campo de estudos. Os escolásticos começaram a fundar suas universidades apenas no século XIII, mas seu método de ensino já era aplicado desde o século V, iniciando por Mânlio Severino Boécio, considerado por historiadores do medievo como "ultimo filósofo Romano e primeiro escolástico", em três tipos de escolas: as monacais (anexas a uma abadia), as episcopais (anexas a uma catedral) e as palatinas (anexas a corte real) (NTISERI; REALE, 2003).

Conseguir um título de doutor em universidades escolásticas se mostrava um grande desafio, o postulante deveria cursar seis anos de artes liberais antes de almejar cursar filosofia e teologia, onde passaria pelo menos mais oito anos. Completado este processo de estudos, o mesmo deveria passar por uma avaliação final, que era uma espécie de argumentação oral onde seus mestres lhe exigiriam comentar um texto, geralmente uma passagem bíblica, a luz dos ensinamentos que lhes foram dados durante os cursos. O comentário deveria ser original e acrescentar ao estudo da Escritura. Terminada a sustentação oral, o estudante seria exposto a uma bateria de perguntas para as quais ele deveria ter uma resposta imediata e objetiva. Só então, os mestres se reuniriam em júri e decidiriam, sempre por unanimidade, se o aluno fazia ou não, jus ao título de doutor (LE GOFF, 2003).

Sobre a escolástica, Le Goff (2003, p. 123) afirma que esta era "[...] mestre do rigor, simuladora de pensamento original na obediência às leis da razão. O pensamento ocidental ficou marcado para sempre por ela, fez através dela progresso decisivos".

Tinham por formação intelectual o Trivium (gramática, dialética e retórica) e o Quadrivium (aritmética, geometria, astronomia e música). As universidades escolásticas deram um passo essencial no que se entende por universalização do estudo, uma vez que foram elas, iniciando pela universidade de Paris, que pela primeira vez aceitaram em seus corpos mestres e estudantes de quaisquer classes sociais, não apenas da nobreza. Apesar de, em grande parte, serem religiosos, foram os primeiros ocidentais a criar um sistema filosófico metodologicamente 
independente da teologia, tornando conhecida no ocidente a metafísica aristotélica (COPLESTON, 1950; ANTISERI; REALE, 2003).

A escolástica não pode ser considerada uma escola de filosofia esquematizada, onde todos os seus pensadores partem da mesma base e chegam em conclusões similares sempre. Ela se define como uma filosofia de escola, praticada dentro do catolicismo, por intelectuais que tinham a sua educação formal, em grande parte, uniformizada, dispondo de conhecimentos comuns e utilizando nomenclaturas similares (CARVALHO, 2007).

Os filósofos escolásticos eram em geral religiosos consagrados das ordens Jesuítas e Dominicanas, apesar de existirem alguns exemplos oriundos das ordens Franciscanas e Agostinianas. Em geral, lecionavam moral e teologia nas universidades pontifícias e mosteiros. Mânlio Severino Boécio e os escolásticos tardios espanhóis, tidos como, respectivamente, o primeiro e os últimos representantes do escolasticismo, estão separados no tempo por um período de onze séculos, o que não faz com que suas ideias percam a consistência. A escolástica não pode ser definida na obra de poucos autores, com linhas de pensamento individuais, ela é o resultado dos esforços combinados de um grupo de intelectuais, organizados dentro da mesma instituição religiosa, por mais de um milênio, onde cada novo autor que surgia buscava referenciar seus antepassados (CARVALHO, 2007).

Assim como seus antecessores, os escolásticos não estavam exatamente interessados em desenvolver uma ciência nova, e sim em analisar fatos da vida cotidiana sobre o ponto de vista moral, o que inclui interações econômicas. É importante se ater para o fato de que as ordens religiosas não têm, nem nunca tiveram, o objetivo de formar economistas. As ordens formavam padres que muitas vezes seriam confessores de seus fiéis, então era relevante o debate de assuntos econômicos como preço justo, direito a propriedade ou usura, para que o pároco decidisse se os atos a ele confessados seriam um pecado ou não. (SCHUMPETER, 1954).

A análise moral feita pelos padres escolásticos das interações humanas é fundamental para o desenvolvimento da ciência econômica, uma vez que esta, é, antes de tudo, um problema filosófico, mesmo que repleta de tecnicidade e instrumentos matemáticos sofisticados. Antes de se avaliar qual o impacto que instituições fortes de defesa a propriedade têm sobre a atividade econômica, deve-se perguntar o que, em si, é a propriedade. O estudo econômico não é um fim em si mesmo, ele deve servir para avaliar os efeitos práticos que suas variáveis de interesse têm na vida dos envolvidos. Sendo assim, o economista, além de executar a prática do ofício, deve sempre se defrontar com o componente ético que o permeia (IONER, 2015).

Por exemplo, para São Tomás de Aquino, a propriedade não se limita apenas a objetos físicos, o direito inicial de cada pessoa é a propriedade sobre si mesmo, o que pode ser entendido como sua independência, tal "direito de propriedade sobre si mesmo" advém a racionalidade do gênero humano. Tal ponderação de Aquino antecipa, em pelo menos quatro séculos, as deliberações iniciais de John Locke sobre direito à propriedade.

Como argumenta Mello (1993, p. 85)

Para Locke [...] a propriedade já existe no estado de natureza e, sendo uma instituição anterior à sociedade, é um direito natural do indivíduo que não pode ser violado pelo Estado. $\mathrm{O}$ homem era naturalmente livre e proprietário de sua pessoa e de seu trabalho [...]. Como a terra fora dada por Deus em comum a todos os homens, ao incorporar seu trabalho à matéria bruta que 
se encontrava em estado natural o homem tornava-a sua propriedade privada, estabelecendo sobre ela um direito próprio do qual estavam excluídos todos os outros homens.

Aquino também defende que, em caso de não existência de proprietário para uma bem, como terras cultiváveis, o primeiro que nele empreender trabalho e se ocupar, terá direito adquirido a sua propriedade, para uso, e seu domínio, para venda (

A propriedade, para Aquino, estava justificada porque os indivíduos cuidarão melhor do que é exclusivamente seu do que o que é de uso geral, uma vez que o livre acesso a um recurso escasso acaba por esgotá-lo, visto que ninguém sofrerá diretamente a perda, antecipando, em pelo menos seis séculos, o que o economista inglês William Forster Lloyd disse e o que viria a ser chamado de "Tragédia dos comuns". Outras justificativas para a propriedade é que os indivíduos se esforçariam mais arduamente para lograr algo para si mesmos do que para a coletividade, aumentando sua eficiência, e que a ordem social seria mais facilmente preservada se as posses fossem distintas (

A concepção de Aquino provavelmente deriva da tradição cristã, onde Deus deu ao homem o domínio da terra para que este se utilizasse dos materiais disponíveis na natureza para moldá-la, a transformando em seu lar legítimo. Sobre os aspectos econômicos pode-se dizer que Aquino compreendeu mais sobre o processo de formação de capital do que sobre a acumulação de riqueza, devido a sua confusa definição de usura.

É neste sentido que aquele grupo de escolásticos, que foram apenas professores de moral e ética, diferentemente de seus pares que se envolveram com estudos sobre moeda, valor, ou preço, têm também a oferecer para o desenvolvimento da ciência econômica, especialmente no ocidente da terra.

Segundo Joner (2015, p. 13)

Através da compreensão do conceito de prudência em Tomás de Aquino, que combinou as observações de Aristóteles e Agostinho, podemos compreender a pesquisa econômica como portadora de valores, já que a sua abordagem é prática e não teórica, afinal, a ciência econômica pode ser livre-de-valor, mas o economista jamais.

A partir do advento do escolasticismo fica difícil definir se o que existe é apenas o pensamento econômico, com alguns insights que derivavam de situações da vida social (da mesma forma que Gregos e Romanos) ou se é a ciência econômica propriamente dita. De qualquer forma, é inegável que estes pensadores do período medieval, além dos escolásticos tardios do século XVII, foram essenciais na reflexão de temas de interesse econômico, como preço justo, inflação e impostos.

Segundo Oliveira e Gennari (2009, p. 22) "A escolástica assumiu a tarefa de realizar essa flexibilização do pensamento econômico da Igreja mediante um conjunto de leis e preceitos morais criados para possibilitar uma boa administração da vida econômica [...]". Dentre todas as contribuições que os escolásticos deram para o desenvolvimento, tanto da ciência, como do pensamento econômico, as mais célebres foram as desenvolvidas pelos professores da Universidade de Salamanca.

Os escolásticos não formam um pensamento homogêneo, e nem se pode esperar isso de uma tradição filosófica que se inicia no século VI com Mânlio Severino Boécio e dura 
até o século XVII, com os últimos escolásticos espanhóis, também chamados de escolásticos tardios. Existiam divergências teológicas, morais e até mesmo artísticas. Apesar disso, existem elementos comuns que os ligam pelo percurso destes onze séculos. Eram católicos de fé e formação intelectual e, baseados nos valores que lhes foram ensinados nos seminários e monastérios, defenderam ideais de liberdade e a maior autonomia do cidadão em relação ao rei ou ao Estado propriamente dito, pois, segunda sua moral, só existe mérito em rejeitar o mal se o indivíduo puder escolher não rejeitá-lo, só há mérito na caridade, se o indivíduo é livre para não fazê-la (ANTISERI; REALE, 2003).

\subsection{Universidade de Salamanca}

A universidade de Salamanca, fundada em 1218, carrega o peso de ser o centro de ensino superior mais antigo da Espanha, e o quarto mais antigo da Europa. É mais jovem somente que as universidades de Bolonha, Paris e Oxford, fundadas respectivamente em 1088, 1096 e 1170. Uma característica comum que une as quatro é que todas elas foram formadas por clérigos católicos do período medieval, em geral professores de moral e teologia, que compartilhavam das ideias escolásticas.

Apesar de ter sido fundada no século XIIV, a Universidade de Salamanca passa a receber maior destaque a partir da contribuição de Francisco de Vitória, monge Dominicano nascido em 1483, que estudou e lecionou em Sorbonne, na França, considerado como grande fundador do direito internacional, por sua extensa e brilhante obra sobre direitos humanos e a forma adequada de relações entre dois países (JONER, 2015).

Francisco de Vitória era, segundo Rothbard (1995, p. 102) "um professor e palestrante brilhante e altamente influente, Vitoria estabeleceu o quadro para a Escola de Salamanca para o resto do século". E ainda completa

Consequentemente, a universidade tinha, pelo menos, 70 cadeiras preenchidas pelos melhores estudiosos da época, fornecendo instrução não apenas no currículo medieval tradicional, mas também em disciplinas tão novas como a ciência da navegação e a língua caldeu.

Como a economia ainda não era uma ciência muito bem definida, os Salamanticienses destacaram-se também em outras áreas, como a produção filosófica e teológica (especialmente a teoria moral), além da área legal, dando enfoque para o jusnaturalismo e o direito internacional. A despeito disso, os Salamanticienses continuaram a tradição escolástica de análise econômica ao defender a não interferência governamental na economia, a imoralidade da taxação forçada e a garantia de direitos negativos, ou seja, proteção do indivíduo em relação ao Estado.

Segundo Roover (1995, p. 168)

Mais ainda do que os escolásticos medievais, os Doutores tardios aderiram a teoria de que a utilidade era a principal fonte do valor e que o preço justo, na falta de regulação pública, era determinado pela estimação comum, ou seja, pela interação das forças de demanda e oferta, sem nenhuma fraude, restrição ou conspiração. Domingos de Soto e Luís de Molina denunciaram como falaciosa a lei formulada por John Duns Scotus (1274-1308), de acordo com a qual o preço justo deveria igualar o custo de produção mais um lucro razoável. 
Segundo Chafuen (2003, p. 84) apud Woods Jr. (2010, p. 160), Luís de Molina, teólogo e jurista espanhol, fundador do Molinismo (doutrina que afirma que Deus tem um controle certeiro e preciso sobre todas as coisas, porém cede ao homem liberdade absoluta para agir por si próprio), argumentava que

O preço justo dos bens não é fixado de acordo com a utilidade que lhes é dada pelo homem, como se, caeteris paribus, a natureza e a necessidade do uso que lhes foi dado determinassem a quantidade de preço [...] Depende da apreciação relativa que cada homem tem para o uso do bem. Isso explica por que o preço justo de uma pérola, que só pode ser usado para decorar, é maior do que o preço justo de uma grande quantidade de grãos, vinho, carne, pão ou cavalos, mesmo que a utilidade dessas coisas (que são também mais nobres na natureza) seja mais conveniente e superior ao uso de uma pérola. É por isso que podemos concluir que o preço justo para uma pérola depende do fato de que alguns homens quiseram conceder-lhe valor como objeto de decoração.

A resolução de São Tomás de Aquino para o preço justo se afasta um pouco de outros escolásticos, ao afirmar que este não era qualquer preço acordado livremente entre compradores e vendedores. Mas sim um preço específico, suficiente para compensar o serviço prestado, apesar de não dar bases claras para definir qual seria esse preço de recompensa. Por outro lado, Aquino se reaproxima de seus correligionários ao defender que o Estado só poderia interferir na economia em caso de absoluta e emergencial necessidade (GENNARI; OLIVEIRA, 2009).

Uma das marcas mais expressivas dos escolásticos era sua inserção na tradição jusnaturalista. Segundo Soares (2008, p. 1)

O jusnaturalismo se afigura como uma corrente jurisfilosófica de fundamentação do direito justo que remonta às representações primitivas da ordem legal de origem divina, passando pelos sofistas, estóicos, padres da igreja, escolásticos, racionalistas dos séculos XVII e XVIII, até a filosofia do direito natural do século XX.

O jusnaturalismo se divide em direito positivo e direito natural. O primeiro faz referência ao fato jurídico em si mesmo, aquele que existe na prática, processual. Enquanto que o segundo corresponde ao que se chama "direito justo", que se compõe de um rol de direitos dos quais todos os seres humanos são titulares, são eternos, imutáveis e universais. Segundo a doutrina jusnaturalista o direito positivo, e todo o processo jurídico, deve ser elaborado em consonância e respeito ao direito justo. Não se pode dizer, sob hipótese alguma, que o direito natural é uma invenção do cristianismo medieval, ele é produto original da escola estóica, apesar de ter sofrido profundas modificações e assumido suas peculiaridades mais sofisticadas com os professores Salamanticenses (BOBBIO, 1999; SABINE, 1945).

Francisco de Vitória utilizou o seu instrumental jusnaturalista para analisar as transformações pelas quais passava a Europa durante a expansão marítima, especialmente sobre um aspecto que é muito caro a qualquer economista: a propriedade. Claramente, a linha jusnaturalista que se utilizava era a teológica, segundo a qual a divindade onipotente, onisciente e onipresente tinha agraciado todos os homens, sem exceção, com direitos adquiridos na primazia de sua existência e, via de regra, eram mantidos pelo resto da vida, dentre eles se elencam o direito à propriedade e a liberdade. Por esse motivo, foi grande defensor dos indígenas latino-americanos, os quais não poderiam ser usados como escravos, ter seus bens tomados ou mesmo governados por espanhóis. Mesmo que não se convertessem ao catolicismo, uma vez que professar outra 
religião, que não a verdadeira, não constitui motivo para a perda, ou suspensão, dos direitos naturais do homem (VIEJO-XIMÉNEZ, 2004).

Segundo Woods Jr. (2005, p. 140)

[...] Vitória argumentou que o homem não era privado do domínio civil por cometer pecado mortal, e que o direito de se apropriar das coisas da natureza para uso próprio (ou seja a instituição de propriedade privada) pertencia a todos os homens, independente de seu paganismo ou de quaisquer outros vícios que eles possuam. Os índios do Novo Mundo, em virtude de serem homens, eram, portanto, iguais aos espanhóis em matéria de direitos naturais. Eles possuíam suas terras pelos mesmos princípios que os espanhóis possuíam para eles.

Neste sentido, pode-se dizer que Vitória é importante para a conceituação e análise de contratos, uma vez que sua defesa em relação aos indígenas serve para garantir o que se pode chamar de segurança jurídica dos mesmos. Isso, de forma que nenhum humano perde sua condição de detentor de seus direitos naturais. Essas considerações de Vitória ecoam até mesmo nos estudos mais modernos. A Nova Economia Institucional, por exemplo, que é uma abordagem que tenta combinar diferentes disciplinas como economia, direito e ciências políticas, considera os contratos como uma instituição formal indispensável para a funcionalidade e a eficiência de qualquer mercado. Além disso, estes contratos devem ser estáveis, onde todos os agentes têm certeza de quais são suas obrigações e direitos, e estes devem ser protegidos. Modo muito similar à segurança jurídica pregada por Vitória para os indígenas (MACEDO, 2012; PONDÉ, 2007).

Ainda sobre o conceito de propriedade, defendido por Vitória, que a considera um direito intrínseco à existência humana e não uma convenção social, é importante ressaltar a diferença entre domínio e uso da propriedade privada, aquele deveria sempre ser particular, enquanto este pode ser público. Isto significa que, em caso de necessidade extrema, uma pessoa, que não é proprietária de algo, pode se utilizar dele em benefício próprio ou de algum terceiro. Como no exemplo de uma tragédia natural, onde a propriedade de algum indivíduo poderia ser utilizada por outro que sofresse graves riscos, cabendo a este restituir financeira ou materialmente o dono legítimo, uma vez que, durante a catástrofe, o que foi perdido foi o uso, mas não o domínio. E é exatamente por este motivo que a propriedade poderia ser utilizada por este indivíduo em perigo, mas não poderia ser vendida por ele, já que isto configuraria transferência de domínio (IONER, 2015).

Como se faz claro, os escolásticos não abriam mão de seus valores morais na elaboração de sua atividade intelectual, sendo assim, o jusnaturalismo medieval assume contornos de teologia cristã. A justiça humana deveria ser uma forma de reproduzir, na medida do que fosse possível, a justiça divina (SOARES, 2008).

\subsection{Teoria Monetária}

A moeda surge no contexto da especialização dos indivíduos e do progresso econômico, como uma substituição do escambo, uma vez que, em uma economia complexa com bens intangíveis, é inviável uma troca direta. Além disso, ela serve como facilitadora das trocas, uma vez que nada mais é do que uma mercadoria de desejo comum. Sem a presença da moeda, seria necessária uma dupla coincidência do escambo. O proprietário do bem A, que deseja 
possuir o bem B, deve encontrar algum proprietário de bem B interessado em trocar pelo bem A. Além de ser claramente um estorvo para os transacionadores, este sistema representaria um atraso para o desenvolvimento econômico, uma vez que, em grande parte, só seriam produzidos os bens de maior valor unitário (LOPES; VASCONCELLOS, 2008).

Milton Friedman (1992, p. 23) apud Matias-Pereira (2010, p. 13), de uma perspectiva clássica, define como:

moeda é tudo aquilo que é aceito por todos em troca de bens e serviços - aceito não como um objeto para ser consumido, mas como um objeto que representa um conteúdo temporário de poder aquisitivo a ser usado para comprar outros bens e serviços.

Já Assaf Neto (2003, p. 34), sob uma perspectiva moderna do que é a moeda, define como "um meio de pagamento legalmente utilizado para realizar transações com bens e serviços. É um instrumento previsto em lei e, por isso, apresenta curso legal forçado. Ou seja, sua aceitação é obrigatória".

Para Keynes, a moeda tinha a função de ser unidade de conta, meio de pagamento e reserva de valor, o que nada mais é do que uma atualização das ideias já concebidas por Aristóteles. Já Marx, defende que a moeda funcione como uma medida universal de valor e controladora dos preços, meio de entesouramento, meio de pagamento e deveria apresentar uma característica universal, fazendo se tornar irrelevante a origem dos transacionadores. Modernamente, a visão Keynesiana é a mais aceita. Já os atributos necessários à moeda são: baixo custo de transação e estocagem, estabilidade do valor, ser relativamente escassa, com elasticidade de produção próxima a zero (AMADO, 2000; MOLLO, 1993; LOPES; VASCONCELLOS, 2008).

Jean de Buridan (1300 - 1358), teólogo e filósofo francês, é considerado por grande parte dos historiadores da economia como o fundador da teoria da moeda. Seu tratado sobre o dinheiro é tido por muitos como o pioneiro no que se trata de explicar um problema de natureza econômica, que incluía análise sobre o fluxo do dinheiro entre países e também sobre a paridade do poder de compra em reinos que usavam moedas diferentes.

A visão de Buridan sobre dinheiro se assemelha muita mais a perspectiva clássica do que a moderna, segundo Woods Jr. (2005, p. 154):

Buridan mostrou como o dinheiro surgiu livre e espontaneamente no mercado, primeiro como uma mercadoria útil e depois como um meio de troca. Em outras palavras, o dinheiro emergiu não por decreto do governo, mas por meio do processo de troca voluntária, que as pessoas descobrem ser dramaticamente simplificada pela adoção de uma mercadoria útil e amplamente desejada como meio.

Buridan inclusive define como a moeda deve ser fisicamente. Ainda segundo Woods Jr. (2005, p. 155):

Essa amplamente desejada, commodity, qualquer que seja, deve, portanto, primeiro ser valorizada por seu papel na satisfação de desejos não monetários. Deve ser facilmente portátil e divisível e ter alto valor por unidade de peso, de tal forma que pequenas quantidades sejam valiosas o suficiente para facilitar quase qualquer transação. 
Jean de Buridan teve um aluno que alcançou tanto destaque quanto o mestre na formulação da teoria monetária e foi significativamente mais bem sucedido na sua vida religiosa, chegando ao posto de bispo de Lisieux. Este foi Nicolas Oresme, que escreveu, na década de 1350, seu Tratado sobre a Origem, a Natureza, o Direito e as Alterações do Dinheiro, onde aplicava os ensinamentos de Buridan ao caso concreto da coroa francesa (ROHTBARD, 1995).

\section{Segundo Rothbard (1995, p. 75):}

a contribuição mais importante da Oresme para a teoria monetária foi enunciar claramente, pela primeira vez, o que veio a ser chamado de "lei de Gresham", isto é, a percepção de que, se duas ou mais moedas forem legalmente fixados em valor relativo pelo governo, então o dinheiro sobrevalorizado pelo governo expulsará o dinheiro subavaliado da circulação.

Oresme também considerava que a moeda tinha duas funções: Ser unidade de medida para facilitar as trocas de bens e serviços e de servir como reserva de valor para o detentor ou para o reino. Considerava que a moeda poderia existir sem prejudicar a eficiência do mercado em qualquer quantidade, antecipando Richard Cantillon em 4 séculos, desde que fosse o suficiente para possibilitar que todas as trocas de uma economia acontecessem. Considerava que o uso da moeda era uma convenção social e precisava atender certos requisitos para continuar sendo admitida pelos usuários e enumerou condições para que uma moeda fosse valorizada. Em sua visão, ela deveria ser fabricada em material durável, ter aparência facilmente identificável, ser amplamente aceita por quem usa e respeitar os costumes comerciais dos usuários. Para que a moeda possa ser facilmente identificável, Oresme considera que ela deve ser feita de um material específico, o qual não deve ser alterado frequentemente. Nela também deve ser impressa uma imagem ou figura que identifique o reino de sua cunhagem e que seja expresso, na própria moeda, o seu valor nominal. A ampla aceitação da moeda é especialmente importante pois permite uma medida comum para diferentes bens, estipulando uma noção de justiça distributiva e também porque permite uma maior especialização de bens e serviços uma vez que o escambo só permite a troca de bens de primeira necessidade, de forma direta.

Na ausência de moeda, o proprietário do bem A teria que encontrar um proprietário do bem $B$ que desejasse fazer essa troca. Na presença de moeda, o proprietário do bem A pode trocar com qualquer um que tenha essa unidade de medida de valor para depois trocá-la pelo bem B. Assim, sendo a existência e a ampla aceitação da moeda fatores que permitem que existam bens ou serviços intangíveis, como um serviço de assessoramento ou contabilidade, onde, em termos físicos, nada é produzido (CUSTÓDIO, 2015).

A crítica das ações governamentais no processo monetário é frequente em escritos de toda a escolástica. Os filósofos dessa escola sempre olharam com muita desconfiança para o processo de multiplicação de moeda e de desvalorização da mesma, usando metal de qualidade inferior na sua produção. Aquino, especialmente, defende que a moeda não pode ser criada a bel prazer do rei, ela deve manter-se com valor estável, para que ele seja um meio de troca confiável e não prejudique os outros preços relativos existentes na economia (JONER, 2015). Aquino também defende que a moeda tem valor apenas para transações e não um valor intrínseco, porque não tem utilidades práticas, como servir de matéria-prima para algum produto. Além disso, ela pode ser usado como meio de enriquecimento do usuário, por ser uma boa reserva de valor. Contudo, criar valor definitivamente não se encontrava entre uma 
das funções naturais da moeda, visto que ela é um simples meio de troca, valorada apenas em convenção dos agentes que a manuseiam. Para ele, a moeda não tem poder de medir diretamente a utilidade dos bens, esta era medida pelo julgamento pessoal do detentor da moeda (GENNARI; OLIVEIRA, 2009; JONER, 2015).

Segundo Woods Jr. (2005, p. 156):

Oresme também concluiu sobre os efeitos destrutivos da inflação. A degradação pelo governo da unidade monetária não serve para um bom propósito, explicou ele. Isso interfere no comércio e aumenta o nível geral de preços. Isso enriquece o governo às custas do povo. Idealmente, ele sugeriu, o governo não deveria interferir no sistema monetário.

Oresme também considerou o valor da moeda no tempo ao afirmar que a função de reserva de valor serviria, entre outras coisas, para transferir poder de compra do presente para o futuro, uma vez que o processo inflacionário faria os preços relativos se alterarem (CUSTÓDIO, 2015).

Com a descoberta das Américas, no século XV, iniciou-se um processo que veio a culminar na alta generalizada dos preços na Espanha do século XVII, decorrente da massiva entrada de metais preciosos, especialmente a prata, do novo mundo na economia local. Martin de Azpilcueta (também conhecido como Doutor Navarro), destacado professor salamanticiense, foi um dos primeiros a, observando a situação que começava a se desenhar na Espanha, especular sobre os efeitos que um aumento na quantidade moeda causariam na economia. Segundo Rothbard (1995, p. 106), Azpilcueta argumentava que:

Toda mercadoria torna-se mais cara quando é muito procurada e tem pouca oferta, e esse dinheiro, na medida em que pode ser vendido ou trocado por alguma outra forma de contrato, é mercadoria e, portanto, também torna-se mais caro quando está em grande demanda e falta de oferta.

Ao analisar comparativamente Espanha e França, Azpilcueta (2004, p. 189) afirma:

Assim, através da experiencia podemos perceber que, na França, quando a moeda é mais escassa que na Espanha, o pão, o vinho, as roupas, e o trabalho, valem muito menos. E até mesmo na Espanha, quando em tempos a moeda é escassa, os bens à venda, assim como o trabalho, custam muito menos do que após o descobrimento das índias, que inundaram o país com ouro e prata. A razão para isso é que o dinheiro vale mais onde e quando é escasso, do que onde e quando é abundante. O que alguns homens dizem que a escassez de moeda reduz o preço dos produtos, surge do fato de que o aumento excessivo do valor do dinheiro faz com que as outras coisas pareçam mais baratas. Exatamente como quando um homem baixo fica ao lado de um homem mais alto, parecendo menor do que quando fica ao lado de um homem da mesma estatura que a sua.

Segundo Azpilcueta (2004, p. 188-189), existem oito fatores que afetam o valor da moeda, são eles:

a. A inexistência de moedas do mesmo metal;

b. Diferentes valores dos metais;

c. Diferentes formas e pesos;

d. A diversidade da terra em que circulavam; 
e. Decisões tomadas pelas autoridades em relação ao contexto onde a moeda circulava ou mudanças na relação entre o valor legal e o valor intrínseco;

f. A diversidade do tempo;

g. A falta e a necessidade de dinheiro;

h. A presença ou ausência de diferentes moedas.

Outro escolástico a tentar definir o valor da moeda foi o professor da Universidade de Valência, Francisco Garcia. Para ele, o valor do dinheiro é dado por uma combinação de três fatores: a oferta de dinheiro disponível; a intensidade da demanda por dinheiro e a segurança apresentada pelo dinheiro. Pode-se inferir aqui que, quando usa o termo "segurança do dinheiro", Garcia se refere a não perda de poder de compra da moeda no tempo, o que chamaríamos de inflação. (ROTHBARD, 1995).

Uma prática muito comum na Idade Média, que também não escapou das críticas dos escolásticos, era a degradação monetária, que consistia em o monarca subtrair metal nobre das moedas em circulação para colocar algum metal de menor qualidade, de modo a criar mais moeda em uma tentativa de expandir a base monetária. Algo que configuraria um processo de senhoriagem, implicando em um imposto oculto. O escolástico, Jesuíta Juan de Mariana, considerava que a cobrança de qualquer imposto sem o consentimento do cidadão era imoral.

Ainda que os impostos fossem consentidos pela população, Mariana defendia que a estes deveriam estar estruturados de uma maneira que hoje chamaríamos de carga tributária progressiva, pois deveriam se concentrar principalmente na renda e minoritariamente no consumo. Ainda assim, na tributação sobre o consumo, os bens de luxo deveriam ser taxados com maiores alíquotas, enquanto os bens básicos para a sobrevivência mais modicamente, de forma a melhorar a distribuição de renda (LAURES, 1928).

Segundo Huerta de Soto (2013, p. 36) Mariana argumentava que “Tampouco pode o rei -e este é um dos aspectos mais importantes do livro da Mariana- obter ganhos pela via de reduzir o conteúdo de metal nobre nas moedas que os cidadãos usam com dinheiro", já que ele havia concluído que "a redução de material nobre nas moedas e, portanto, o aumento no número das mesmas é uma forma de inflação (mesmo que este termo não fosse utilizado na época), que inevitavelmente levará a um aumento dos preços". Mariana foi pioneiro na compreensão do que mais tarde seria chamado de senhoriagem.

De Monetae Mutatione, de Mariana, é um dos primeiros tratados que se tem notícia sobre dinheiro. Nele, o padre acusa o rei Felipe III da Espanha por degradar a moeda nacional ao diminuir o seu peso em cobre e aumentar seu valor de face sem justificativa alguma. Mariana afirmou que esta degradação monetária prejudicava o comércio, uma vez que as partes envolvidas nas trocas passavam a desconfiar da moeda e, por isso, aumentavam os preços. Ao mesmo tempo, a degradação era uma forma de roubar o cidadão, pois ele via seu poder de compra diminuído em favor do Rei. Mariana argumenta que há dois valores para o dinheiro, o natural (intrínseco) e o legal (extrínseco), o primeiro equivale a quantidade e a qualidade do metal que compõe a moeda, o segundo é fixado pela autoridade estatal. Ele argumenta que os dois valores devem ser os mais próximos possíveis, porque, do contrário, os compradores e vendedores poderiam suspeitar de degradação da moeda, tendo como consequência a inflação. Apesar de ser um metalista, o que é inteiramente compreensível, visto que Mariana viveu 
durante o auge do mercantilismo, esta desconfiança, para com o trato da autoridade real em relação à moeda, o fez considerar que, em alguns casos (como quando o rei absorve grandes vantagens pecuniárias rebaixando o valor da cunhagem), poderia ser aconselhável a utilização de moedas feitas de outros matérias, como couro ou papel (IORIO, 2017; LAURES, 1932).

Mariana analisa, até mesmo, as vantagens e desvantagens da inflação. Para ele, em situações onde os preços estão se elevando, no curto prazo, haverá uma maior abundância do dinheiro, o que leva a um aumento da oferta de empréstimo e uma diminuição dos juros. A diminuição dos juros aumenta a atividade produtiva, sendo assim, haverá uma maior procura por trabalho e o desemprego será menor, em suma, no curto prazo, uma menor taxa de desemprego está associada a uma maior inflação. O economista neozelandês William Phillips, ao desenhar sua famosa curva cerca de 400 anos depois, chegaria a mesma conclusão, apesar de se utilizar de um instrumental muito mais sofisticado (LAURES, 1928).

É importante ressaltar, ainda, que as reflexões de Mariana não tinham por objetivo uma análise numérica ou utilitarista. Inspirado pelo pensamento de São Tomás de Aquino, empreendia sua pesquisa econômica tendo em vista uma melhora do bem-estar geral. Exemplo disso é seu estudo sobre a desvalorização da moeda criada pela entrada de metais na Europa, originários do Novo Mundo, onde defendia que a desvalorização deveria ser combatida enfaticamente, pois sua presença aumentava os preços, encarecendo o custo de vida dos súditos do rei, especialmente dos mais pobres (IONER, 2015).

Thomas de Vio (1469-1534), também conhecido como Cardeal Caetano, foi um frade dominicano e exegeta de origem italiana, que ficou marcado na história por ser o grande opositor de Martinho Lutero, defendendo a doutrina romana frente a iminente revolta protestante. Porém, não só no campo teológico Caetano obteve destaque, no início do século XV, escreveu sua Magnum opus, intitulada De Cambiis, onde, segundo Woods Jr. (2005, p. 157):

[...] apontou que o valor do dinheiro no presente poderia ser afetado pelas expectativas em relação ao mercado no futuro. Assim o valor do dinheiro no presente poderia variar se as pessoas esperassem certos eventos de grande impacto no futuro, como doenças e guerras.

\section{Segundo Rothbard (1995, p. 100), Caetano em sua obra De Cambiis:}

estabeleceu a defesa mais completa e incondicional ainda escrita do mercado cambial [...] Ele mostrou claramente que o dinheiro é uma mercadoria, particularmente quando se deslocam de uma cidade para outra e, portanto, está sujeito às leis de demanda e oferta que regem os preços das commodities.

Além disso, Caetano demonstrou que era impossível a existência do comércio internacional sem o mercado de câmbio e que o mesmo era completamente lícito. A retórica é simples. Caetano considerava que o papel do comerciante era legítimo. Então, como a moeda nada mais é do que um produto comercializável, o trabalho do banqueiro de câmbio também é legítimo. No mercado de câmbio, como nos outros, o preço justo para uma moeda era aquele livremente acordado entre compradores e vendedores. (IORIO, 2017).

Mas, antes mesmo de Caetano, outro teólogo escolástico já tinha redigido uma defesa do mercado de câmbio. O padre Franciscano Alexander Bonini, professor da Universidade de Paris, durante os séculos XIII e XIV, em sua obra Tratado sobre a usura, apesar de atacar os 
ganhos obtidos com cobranças de juros, apresentou uma defesa das transações cambiais como forma de lucro. Para ele, o dinheiro não tinha apenas a função de meio de troca de bens, eles poderiam ser trocados entre si mesmos e por diferentes preços, uma vez que o valor da moeda não pode ser definido por uma lei, mas sim pelo peso e material com a qual as mesmas tenham sido fabricadas. Bonini foi um dos primeiros a observar que a demanda por dinheiro pode variar, e de fato varia, com o decorrer do tempo. Assim, a moeda pode sofrer mudanças de valor, mesmo que fisicamente permaneça a mesma, podendo também ter alterações em seu preço relativo, se comparadas com outras moedas estrangeiras (ROTHBARD, 1995).

Um dos discípulos de Bonini foi São Bernardino de Siena, o qual seguiu os passos do mestre ao defender o mercado cambial, uma vez que as transações cambiais eram conversões de moeda e não empréstimos, não sendo, portanto, como a proibida usura. Para Bernardino, o mercado cambial deveria ser defendido, inclusive pela Igreja, pois somente assim seria possível a existência do comércio exterior, uma vez que a cunhagem de um reino certamente não seria aceita em outros. É conveniente lembrar que tanto Bonini (1270 - 1314) como São Bernardino (1380 - 1444) antecedem os pós-escolásticos, que só surgiram depois do século XV (ROTHBARD, 1995).

\subsection{Teoria do Valor}

A contribuição mais importante dos escolásticos para o desenvolvimento da economia é também a característica que os diferencia da maior parte das correntes econômicas existentes até o momento (e também parte das futuras). Os escolásticos acreditavam que o valor dos bens e serviços derivavam de fatores subjetivos e não de fatores objetivos. Segundo Joner (2015, p. 37), "os doutores notaram que o valor dos bens possuía um caráter subjetivo, que impossibilitava uma mensuração uniforme de um determinado bem pela população como um todo".

Segundo Joner (2015, p. 32):

Vitória analisou o valor dos bens no mercado a partir de uma lei natural e não de uma justificação objetiva. Para ele, "quando Pedro vende trigo, o comprador não precisa considerar o dinheiro gasto por Pedro ou o seu trabalho, mas sim a estimação comum de quanto vale o trigo.

Segundo Woods Jr. (2005, p. 158) “influenciados em parte pela própria análise e em parte pela obra de Santo Agostinho "A Cidade de Deus", esses pensadores católicos compreenderam que o valor deriva não de fatores objetivos como o custo de produção ou o montante de trabalho empregado, mas da valoração subjetiva que os indivíduos dão".

Em consonância, Joner (2015, p. 25) afirma que Agostinho “[...] foi o primeiro a avaliar que o valor e o preço de um determinado bem são baseados na utilidade deste para o homem". Porém, antes mesmo dos escolásticos tardios espanhóis, já existia dentro da corrente de pensamento, um seleto grupo que defendia os fatores subjetivos como determinantes do preço. Um dos mais destacados foi Jean Pierre Olivi, teólogo franciscano do século XIIV. Segundo Rothbard (1995, p. 60):

[...] em dois tratados sobre contratos, um sobre usura e outro sobre compras e vendas, apontou que o valor econômico foi determinado por três fatores: escassez (raritas); utilidade (virtuositas); e desejabilidade (complacibilitas). O efeito da escassez, ou o que agora chamaríamos de "oferta", 
é claro: quanto mais escasso é um produto, mais valioso é, e, portanto, maior o preço. Quanto mais abundante o produto (quanto maior a oferta), por outro lado, menor o valor e o preço.

Na mesma linha de raciocínio, Chafuen (2003, p. 84) argumenta que o Cardeal Jesuíta Juan de Lugo havia desenvolvido um argumento original em favor do valor subjetivo:

o preço flutua não por causa da perfeição intrínseca e substancial dos artigos - uma vez que os ratos são mais perfeitos que o milho, mas valem menos - mas por sua utilidade em relação à necessidade humana e somente por causa da estimativa seu preço é muito maior. E devemos levar em conta não só a estimativa de homens prudentes, mas também da imprudência, se eles são suficientemente numerosos em um lugar. [...] A estimativa comunitária, mesmo que tola, aumenta o preço natural dos bens, já que o preço é derivado da estimativa.

Para Tomás de Aquino, no momento de definir o valor subjetivo que dá a determinada mercadoria, o homem pondera o trabalho efetuado pelo comerciante, e não só pelo produto, bem como o risco que este comerciante assume para poder transportar os bens de um reino ao outro. É importante reforçar que Tomás de Aquino viveu no século XIIV, na região do Lácio, onde foi fundada a cidade de Roma, capital do império, e estava inserido no contexto de uma economia feudal, onde grande parte do comércio se dava nos burgos. Ou seja, do lado de fora das muralhas que protegiam as cidades, por pessoas, em geral, de menor poder aquisitivo, que enfrentavam riscos como saqueadores e intempéries (WOODS JR., 2005).

Segundo Rothbard (1995, p. 52-53):

São Tomás era claramente um Aristotélico ao adotar a visão incisiva deste último de que o determinante do valor de troca era a necessidade, ou utilidade, dos consumidores, expressa em sua demanda por produtos [...]. Além disso, na Summa, Tomás de Aquino observa a influência da oferta e da demanda nos preços. Uma oferta mais abundante em um lugar tenderá a baixar o preço naquele lugar e vice-versa.

A teoria do valor subjetivo está diametralmente em oposição com a teoria do valor objetivo. Por influência dos clérigos católicos, a teoria subjetivista encontrou mais respaldo na própria Espanha, mas também na Itália e, principalmente, na França, influenciando os pais da Fisiocracia: François Quesnay e Anne Robert Jacques Turgot. Já a teoria objetivista do valor, encontrou espaço em países que foram mais fortemente influenciados pelo protestantismo, como o Reino Unido e Alemanha. $\mathrm{O}$ valor objetivo foi tão determinante na formação dos economistas destes países que se converteu em parte indissociável dos trabalhos de Karl Marx, Adam Smith e Davi Ricardo, por exemplo.

Segundo Woods Jr. (2005, p. 161):

A teoria do valor subjetivo também equivale a uma refutação direta à teoria do valor do trabalho, mais intimamente associada a Karl Marx, o pai do comunismo. [...] Esse valor econômico objetivo foi baseado no número de horas de trabalho que entraram na produção de um bem em particular.

Woods Jr. (2005, p. 163) ainda completa "os economistas franceses e italianos, influenciados pelos escolásticos, mantiveram, em geral, a posição correta; foram os economistas britânicos que divergiram tão tragicamente em linhas de pensamento que culminaram em Marx". 
Apesar de apresentar a formulação mais desenvolvida do valor trabalho, Marx não foi o único teórico a tratar do assunto. David Ricardo considerava que o valor de uma mercadoria dependia da quantidade relativa de trabalho aplicada a sua produção. Ele acreditava que deveria haver uma "mercadoria padrão", a qual seria uma medida de todas as outras, esta "mercadoria padrão" deveria ter um preço que não variava de acordo com outros preços ou com os salários dos trabalhadores, pois a sua produção necessitaria de uma quantidade de trabalho aplicado eternamente invariável. Todos os esforços de Ricardo para encontrar esta mercadoria foram frustrados.

Para Adam Smith, o preço real dos produtos era uma função da quantidade de trabalho necessário para sua produção e a quantidade de trabalho necessário para poder comprá-lo. A riqueza, portanto, é uma relação sobre quanto domínio sobre o trabalho alheio o indivíduo tem. Assim, o preço de alguma mercadoria representa uma quantidade de riqueza equivalente às horas de trabalho necessárias para obtê-la. Stuart Mill também considerava que o trabalho era o principal fator para se definir o preço das mercadorias, mas não o único. Para ele, também eram relevantes o valor dos instrumentos de produção utilizados e a quantidade de capital empregada, assim, o trabalho só poderia ser o único valor a afetar os preços se as quantidades de capital fossem idênticas em todas as indústrias. O que havia em comum em todas essas análises é que elas consideravam que os preços poderiam ser determinados por fatores objetivos (CARCANHOTO, 1991; OLIVEIRA; SCOVILLE, 2014).

A teoria do valor-trabalho divide a produção entre trabalho produtivo e trabalho não produtivo. O primeiro é o simples processo de transformação dos elementos disponíveis, onde existe produção de valor de uso. Em suma, é o trabalho que produz mais-valia para o capitalista, que valoriza monetariamente o produto. Porém, este trabalho produtivo não é necessariamente material, um mestre que ensine um ofício para um estudante, na intenção de enriquecer o capitalista que for usar seu trabalho futuramente também é um trabalho produtivo. Já o trabalho improdutivo é aquele que pode fazer a transferência de renda, mas não cria riqueza diretamente por transformação dos elementos disponíveis, é, por exemplo, o comércio, onde um indivíduo compra um determinado produto a um preço mais baixo e, por meio de especulação, o vende a um preço mais alto. Nenhum valor foi criado neste processo, mas o comerciante está mais rico. Outros trabalhos improdutivos são a contabilidade, as atividades administrativas ou o próprio trabalho despendido no processo de criação de moeda física (MARX, 1984).

Para Gennari e Oliveira (2009, p. 46), a mais-valia pode ser entendido de maneira mais simplificada como "o valor criado por uma jornada de trabalho é constituído de duas partes: uma que remunera o trabalhador e outra que constitui o excedente, o trabalho não pago, parcela que Marx denominou posteriormente mais-valia".

Saber o conceito de trabalho produtivo é importante, neste ponto, pois assim é possível chegar ao cerne da teoria do trabalho objetivo: a grandeza de valor de uma mercadoria pode ser medida pela quantidade de valor agregado a ela, atribuída pelas horas de trabalho produtivo gastas em sua confecção. Porém, o trabalho que agrega valor para Marx (e que pode ser considerado como produtivo) é o abstrato, que é aquele destituído de qualidade, ou valoração subjetiva, e que pode ser medido por tempo. 
O valor de um produto, então é medido pela quantidade de horas gastas por todas as partes envolvidas na produção de bem. Fica bem claro assim, a oposição das ideias escolásticas sobre valor, onde este deriva das preferências e desejos do consumidor, todos subjetivos e sem necessariamente seguir uma determinada lógica (o valor pode ser dado por paixões transitórias, por exemplo), além, da raridade deste produto no mercado, e da teoria do valor-trabalho, onde a mercadoria pode ser valorada mediante fatores objetivos e que respeitam sempre uma mesma lógica de mensuração, como horas despendidas na produção (GENNARI; OLIVEIRA, 2009).

São Bernardino de Siena, sacerdote franciscano, que viveu entre os séculos XIV e XV, deu continuidade as ideias de Olivi e as aprofundou, quando aplicou as suas ideias de valor subjetivo ao "salário justo", porque, na sua visão, o salário era apenas mais uma mercadoria, que teria seu "preço justo" definido pela livre interação entre compradores e vendedores. Segundo Rothbard (1995, p. 83), Bernardino argumentava que:

Os salários são o preço dos serviços trabalhistas [...] e, portanto, o salário justo ou de mercado será determinado pela demanda por mão-de-obra e pelo fornecimento disponível de mão-deobra no mercado. A desigualdade salarial é uma função das diferenças de talento, habilidade e treinamento.

Em uma tentativa de complementar Bernardino, Francisco de Vitória reafirma que, para bens sem um mercado comum, com poucos compradores e vendedores, os preços deveriam ser negociados individualmente, sendo determinados pelas duas partes do câmbio. $\mathrm{O}$ mesmo se aplica para itens "luxuosos", uma vez que o comprador está usando de seu livre arbítrio para despender uma voluptuosa quantidade de dinheiro em algum bem que não é necessário, ou pode ter um substituto mais barato. Porém, quando se tratam de itens básicos para a sobrevivência e manutenção da dignidade humana, Vitória argumenta que não pode ser cobrado um preço qualquer pelo vendedor, pois o comprador não estaria completamente livre de coerção, ele deve comprar para sobreviver, então nestes casos, é admitida interferência externa (o que pode ser entendido como interferência estatal) na determinação do preço justo do item. (ROTHBARD, 1995).

\subsection{Mercado, comércio e usura}

Os filósofos católicos medievais, em grande parte, sempre se demonstraram contra o que se chamava de usura. Mas, apesar de serem os mais lembrados por essa condenação, não foram os únicos a fazê-las, tampouco os primeiros. A filosofia pagã ocidental já contava com inúmeros críticos a esta forma de lucro, dentre eles, Aristóteles, que marca claramente essa posição em sua obra "Política". Como São Tomás de Aquino é a grande ponte entre Aristóteles e o catolicismo, ao mesmo tempo em que é visto como referência para boa parte dos filósofos escolásticos nascidos depois do século XIIV, é fácil perceber a origem do movimento escolástico de repudia a usura (RODRIGUES, 2015).

Definir usura, até os dias presentes, é um trabalho árduo. O que é ponto pacífico entre historiadores e filósofos é que, quando se fala em usura, se faz uma referência ao ganho ou rendimento, por meio de juros, de certa quantia de capital emprestado. Segundo Le Goff (2014, s/p): 
O código de direito canônico exprime melhor a atitude da Igreja em face da usura no século XIII: usura é tudo aquilo que se pede em troca de um empréstimo para além do empréstimo em si mesmo; pedir isso é um pecado proibido pelo Antigo e o Novo Testamento; a só esperança de um bem de retorno para além do bem emprestado é um pecado; as usuras devem ser integralmente restituídas a seu verdadeiro dono; preços mais altos por uma venda a crédito são usuras implícitas.

A crítica de Aquino a Usura está longe de existir em um sentido estritamente econômico, ela é mais de caráter moral. Para ele, o trabalho mecânico, ou mesmo, o intelectual tem valor positivo e se afastar deles poderia representar riscos a alma humana, como o pecado capital da avareza. Além disso, Aquino considerava que lucrar com empréstimos configurava uma imoralidade, uma vez que, para ele, o dinheiro é totalmente consumido pelo seu proprietário em uma troca, assim o direito de uso e o direito de domínio do dinheiro são a mesma coisa. Então, cobrar juros pelo empréstimo é cobrar duas vezes pelo mesmo item, uma vez pelo seu domínio e uma vez pelo seu uso. Antes, Guilherme de Auxerre, filósofo escolástico e reitor da Universidade de Paris, nominalmente citado por Aquino como uma de suas maiores referências, fez um ataque violento à prática da usura, classificando-a como "má e monstruosa", até mesmo pior que o assassinato, pois este, sob certas circunstâncias de legítima defesa, pode ser justificado, a usura jamais (GENNARI; OLIVIVEIRA, 2009; ROTHBARD, 1995).

A partir do século XIV, porém, parece haver, nos documentos oficiais da igreja, uma redefinição do que seria a condenável usura: Nem toda cobrança de juros era pecaminosa, apenas aquela exagerada e injusta. Também após o século XIV, a usura deixa de ser crime comum, com punições similares as que se aplicavam a casos de furto, passando a ser um "crime contra as finanças", e se aproximando muito do que o direito moderno chama de "agiotagem".

Essa mesma tendência de aceitação dos ganhos com empréstimo por parte da Curia Romana, que se manifesta a partir do século XIV, é refletida nos filósofos escolásticos que começavam a se destacar nesta época. Como é o caso de Gabriel Biel, importante canonista alemão e histórico professor da Universidade de Erfurt. Biel defendia que ganhar juros com um empréstimo era o mesmo que comprar um contrato de seguro, pois não havia nenhuma garantia de que o tomador do empréstimo iria retornar ao poupador o capital emprestado, portanto, se manter contratos de seguro era lícito, lucrar com juros também deveria ser. Vale lembrar que o argumento de Biel tem grande impacto pois o mesmo viveu durante a expansão marítima europeia, que era de grande importância para a expansão do catolicismo, uma vez que havia todo um novo continente a catequizar, e que não seria possível sem os chamados "contratos e dinheiro e risco marítimo", que, segundo Pereira (2013, p. 5) "consistiam num empréstimo dado a um navegador, e que previam uma cobrança maior no caso de sucesso da viagem e o perdão da dívida se a embarcação e a carga fossem perdidas" (LE GOFF, 2014; PIMENTEL, 1974; ROTHBARD, 1995).

O jesuíta Leonard Lessius, pioneiro na aplicação da ética a práticas comerciais, foi o primeiro a utilizar, explicitamente, o que pode ser traduzido como custo de oportunidade. Para Lessius, a cobrança de juros sobre o empréstimo de capital era perfeitamente justificável, pois o emprestador, além de correr o risco de sofrer um calote, ainda fica, temporariamente, sem a posse do dinheiro, que poderia ser utilizado em outros investimentos lucrativos. $\mathrm{Ou}$ seja, para emprestar dinheiro para um investidor, ele mesmo perdia uma chance de investir. Lessius, paralelamente, também especulou sobre o preço justo. Para ele, havia dois: aquele 
determinado pelo mercado ou aquele determinado pelo governo (quando este fosse legítimo), porém, o preço de mercado deveria ser o efetivo sempre que ele fosse menor que o preço definido governo, ou quando o segundo estivesse defasado (IORIO, 2017; ROTHBARD, 1995).

Por conta deste tipo de tratamento, que era dado a cobrança de juros, formou-se uma certa linha de análise histórica que associa a igreja católica a um entrave no desenvolvimento econômico e do mercado (uma vez que empréstimos, e a consequente cobrança de juros, são necessários para grandes empreendimentos) ou, mais especificamente, tivesse inibido o desenvolvimento do capitalismo. Porém, é importante deixar claro que, antes do século XIIV, a Europa contava com uma economia agrária, ainda marcada fortemente pelo escambo, onde o dinheiro desempenhava apenas papel secundário nas relações de troca e ainda não existiam os grandes investimentos especulativos que se iniciaram com a expansão marítima (CAMPOS, 1952).

Outra acusação comumente feita é que as bases do pensamento católico condenam o enriquecimento pessoal, porém, segundo Le Goff (2014, s/p)

a literatura da alta Idade Média só raramente fala em "ricos", palavra que designa antes os poderosos do que os donos de fortunas [...]. Um dos textos mais célebres e mais utilizados na Idade Média é o de Isidoro de Sevilha (cerca de 570-636) que, em suas famosas Etimologias, situa o amor ao dinheiro à frente dos pecados capitais, promete aos ricos o inferno e lembra a parábola do rico e do pobre Lázaro, mas na verdade não condena totalmente a riqueza e os ricos. Como a riqueza foi criada por Deus, se os ricos consagrarem sua fortuna ao bem público e às esmolas estão justificadas [...].

Nem mesmo as acusações de serem promotores e advogados da pobreza e atuarem contra o desenvolvimento do mercado e da economia, por sua recusa à propriedade privada, feitas contra os franciscanos procedem, uma vez que a doutrina da ordem, fundada por São Francisco de Assis, diz que seus membros devem abrir mão de suas riquezas, voluntariamente, para compartilhá-las com os pobres, mas para alguém abrir mão de riqueza é necessário que, anteriormente, tenha tido meios para acumulá-la (IORIO, 2017).

Ao contrário do que aponta uma linha historiográfica que se tornou muito popular, especialmente depois da publicação, em 1904, por Max Weber, de A Ética Protestante e o Espirito do Capitalismo, o pensamento escolástico e pós-escolástico sempre se mostrou muito favorável a uma economia de mercado desregulada e à atividade comercial. As principais provas disto talvez sejam a incessante defesa dos escolásticos de que o valor de bens ou serviços seria sempre relativo, sendo definido pela totalidade de compradores e vendedores, que juntos formam o que chama-se de mercado, e não por fatores objetivos que podem ser determinado por uma legislação. Além da também argumentação de que o preço justo é aquele livremente acordado entre os entes envolvidos na transação, desde que estes estejam livres de coerção. (WOODS IR., 2005).

Segundo Aquino (1980, s/p) apud Gennari e Oliveira (2009, p. 24):

[...] a negociação, em si mesma considerada, não visando nenhum fim honesto ou necessário, implica em certa vileza. Quanto ao lucro, que é o fim do negócio, embora não implique por natureza nada de honesto ou necessário, também nada implica de vicioso ou de contrário à virtude [...] nada impede um lucro ordenar-se a um fim necessário ou mesmo honesto. E, desse 
modo, a negociação se torna lícita. Assim, quando buscamos, num negócio, um lucro moderado, empregando-o no sustento da casa ou mesmo ao socorrer os necessitados. Ou ainda quando fazemos um negócio visando a utilidade pública, para não faltarem à pátria as coisas necessárias à vida; e buscamos o lucro, não como um fim, mas como paga do trabalho.

Tomás de Aquino ainda considerava que o comércio não era intrinsecamente virtuoso, mas que era indispensável para o bom funcionamento de um mundo imperfeito e que poderia ser completamente justificado, desde que fosse feito para garantir a subsistência do comerciante ou dos que dele dependessem ou quando o comércio trouxesse desenvolvimento para a comunidade na qual o empreendedor estava inserido, ou nas que seu empreendimento afetavam. Sendo assim, só existia um comércio injustificável para Aquino, aquele que servia apenas para enriquecer o comerciante, que já tinha mais do que o necessário para sobreviver, ao mesmo tempo que não beneficiasse a comunidade, ou até mesmo o Estado, na suposição de que este reverteria o benefício para os cidadãos. Fica claro que Aquino não apresentava empecilhos morais para a obtenção do lucro, o problema era buscar a acumulação de riqueza como fim último. (GENNARI; OLIVEIRA, 2009).

Corroborando com o exposto acima, Rothbard (1995, p. 53-54) defende que

Não deveria surpreender que Aquino, em contraste com Aristóteles, fosse altamente favorável às atividades do comerciante. O lucro mercantil, declarou ele, era um salário para o trabalho do comerciante e uma recompensa por assumir os riscos do transporte. Em um comentário à política de Aristóteles [...] particularmente importante foi o breve esboço de Tomás de Aquino sobre o benefício mútuo que cada pessoa obtém da troca. Como ele colocou na Summa: "comprar e vender parece ter sido instituído para o benefício mútuo de ambas as partes, uma vez que é preciso algo que pertence ao outro, e inversamente."

Aquino ainda considerava que existia uma outra prerrogativa para justificar o comércio: as trocas deveriam ser efetuadas por livre interesse de comprador e vendedor, porque cada uma das partes tem interesse no que a outra detém e acreditam estar auferindo ganho com a troca. Bernardino de Siena concordava com Aquino ao defender que não existe nenhuma moralidade absoluta e intrínseca ao comércio, este poderia ser tanto legal como ilegal. Para ele, o comércio tem caráter excepcionalmente positivo quando cumpre com alguma função social, como transportar commodities (especialmente as essenciais) de países onde há excedente para países onde há escassez, possibilitando que a população desfrute de algum produto que, na ausência do comerciante, seria inalcançável. O comerciante também era importante porque possibilitava que outros indivíduos realizassem seus trabalhos e obtivessem seus sustentos, quando, por exemplo, faziam o transporte e o armazenamento de matérias necessárias à produção artesanal. Quando o comerciante cumpria com esta importante função social, seus lucros não eram condenáveis, pelo contrário, eram dignos os pagamentos do serviço realizado e as despesas e riscos que ele assumia. Um contemporâneo de Bernardino a também advogar pela licitude do lucro empresarial foi o teólogo alemão Johanes Nider. Ele afirmava que o lucro do empresário não era somente um pagamento pelos riscos do transporte e do armazenamento, era também uma forma de recompensar o tempo gasto para adquirir conhecimento de mercado e manter relações comerciais com os potenciais compradores. No lucro do comerciante também estava contido a recompensa por sua diligência e cuidados para com a mercadoria. Outro a verificar a função social do comércio foi Juan de Mariana, um século após Bernardino. 
Para ele, o comércio era indispensável para a prosperidade do reino (apesar de criticar o comércio meramente motivado por lucro), na medida em que ele equilibrava as necessidades e o excedente de produção de diferentes países, de modo a distribuir melhor os produtos. Assim, cada país poderia dispor de tudo o que precisava para escoar seu excedente, fornecendo abundância de todos os produtos, para todos os países. Além disso, quanto mais estimulado fosse o comércio, mais concorrência existiria e os preços seriam menores, diminuindo o número de necessitados. Apesar de utópico, o pensamento de Mariana traduz bem os benefícios do livre comércio, especialmente para os mais pobres (JONER, 2015; LAURES, 1928; ROTHBARD, 1995).

Bernardino ainda fez uma grande observação em relação à pratica do monopólio que, segundo ele, é tão terrível para o mercado e para os cidadãos, por encarecer preços e impedir o fluxo natural dos bens, aumentando a pobreza ao passo em que é corrosivo para com o poder de compra. Em sua visão, era algo que deveria não apenas ser considerado um crime punível com prisão, como um pecado punível com excomunhão. Para ele, não existia livre comércio se não existisse concorrência. Outro escolástico, discípulo de Aquino, a defender o benefício do comércio para todas as partes envolvidas, foi Ricardo de Middleton. Como a maioria dos seus companheiros, Ricardo considerava que a necessidade e a utilidade de determinado bem é quem ditavam seu valor econômico, e o preço justo era aquele determinado comumente pelos consumidores em vista de suas necessidades particulares. Sobre o comércio, ele afirmava que, quando desregulado e justo, ele será benéfico para os dois envolvidos, pois o vendedor tem mais necessidade no dinheiro do comprador do que no bem que ele possui. Já o consumidor, contrariamente, tem mais necessidade no bem que o vendedor possui do que no seu próprio dinheiro. A mesma justificativa que Ricardo utilizava para o comércio entre dois indivíduos também serviu para defender o comércio internacional, uma vez que, se um país hipotético fosse produtor de uma grande quantidade de material A, suficiente para atender as suas próprias necessidade e ainda gerando excedente, ao passo que um outro país hipotético fosse grande produtor de material B, nas mesmas condições que o primeiro, seria benéfico para ambos um intercâmbio dos excedentes, uma vez que diversificariam ambas as economias, com produtos que, caso não existisse o comércio internacional, seriam descartados como sobras ( $\underline{\text { ROBBINS, }}$ 1998; ROTHBARD, 1995).

Os escolásticos tardios espanhóis mantiveram a posição dos discípulos diretos de Aquino na defesa do comércio e do lucro. Os jesuítas Francisco Suárez e Luís de Molina estabeleceram uma forte argumentação em favor do mercado em seus trabalhos acadêmicos dentro da Universidade de Salamanca, ao afirmarem os benefícios sociais do comércio na geração de renda e diminuição da pobreza, ajudando a descontruir a imagem de que o trabalho comercial seria estéril. Além disso, para eles, a simples especulação financeira também era justificável e benéfica pois criava condições necessárias para a expansão do comércio ao permitir a transferência de fundos para empreendedores. Domingo de Soto, outro professor salamanticiense, coloca a atividade comercial como requisito para o desenvolvimento civilizacional, uma vez que permitia trocas pacíficas e livres entre duas partes igualmente interessadas (GREGG, 2004).

É impossível negar que, na alta Idade Média, período compreendido entre o final do século $V$ e o início do segundo milênio, havia uma certa antipatia por parte dos representantes do escolasticismo para com o comércio e a atividade empresarial. Muito provavelmente, em decorrência do pensamento neoplatônico e aristotélico que, em grande parte, formaram a 
filosofia medieval no ocidente. Aristóteles considerava o comércio como força meramente especulativa, incapaz de criar qualquer riqueza. Platão, no mesmo sentido, tratava a atividade comercial como corrosiva do tecido social, pois criva conflitos ao concentrar nas mãos de poucos a riqueza, que, em sua visão, deveria ser comunitária (da pólis) e por ser incapaz de produzir bem-estar e desenvolvimento social.

Porém exposto isto, também é necessário dizer que esta hostilidade ao mercado apresentada pelos primeiros escolásticos é deixada de lado, ao ponto de ser substituída por uma defesa ao comércio, pelos escolásticos da baixa Idade Média, como, destacadamente, Aquino, Bonini, Ricardo de Middleton e Bernardino de Siena, sem desprezar também, as contribuições menores, porém ainda importantes, feitas pelos escolásticos tardios como Francisco de Vitória e Juan de Mariana, ou como o menos celebrado, porém não menos relevante, professor de Salamanca, Jeronimo Castillo de Boabadilla que, segundo Iorio (2017, s/p) “[...] defendeu a competição dinâmica nos mercados como um processo e não como o estudo de casos de equilíbrio, antecipando Carl Menger, Ludwig von Mises, Ludwig M. Lachmann (1906-1990) e Israel M. Kirzner em quatrocentos ou quinhentos anos!". Em última instância, pode-se dizer que a grande contribuição do escolasticismo para o desenvolvimento do mercado foi a legitimação, tanto moral quanto legal, da atividade comercial.

\section{Conclusão}

O estudo teve por alvo também abrir a literatura no assunto específico, uma vez que a contribuição escolástica para o desenvolvimento da ciência econômica sofre com um déficit de produção acadêmica, especialmente em língua portuguesa.

Com a formulação do referencial teórico, foi possível apresentar o pensamento econômico antes dos clássicos como Smith, Ricardo e Marx. O que, apesar de muitas vezes ser deixado de lado pelas principais linhas de análise histórica, é de suma importância, uma vez que o pensamento econômico precede e forma a ciência econômica, ao criar as bases filosóficas que, posteriormente, seriam usadas por economistas renomados. Juntamente com os ferramentais empíricos e matemáticos para a estruturação desta ciência.

Discutiu-se o que significa ciência econômica dentro dos seus nuances e qual o papel do economista dentro do campo das ciências sociais, bem como sua indissociabilidade para com outras formas de conhecimento, como a filosofia ou a sociologia. Foi demonstrado que, apesar de certas imprecisões, filósofos do mundo antigo, especialmente gregos e romanos, foram os primeiros a discutir conceitos que são utilizados até hoje. Como mercado, comércio, divisão social do trabalho. É difícil acreditar que existiria o laissez-faire sem o arcabouço jurídico fornecido pelos romanos, ou mesmo que nosso conceito atual de propriedade seria o mesmo.

Quanto aos escolásticos, que consistiram na parte fundamental do trabalho, houve um esforço considerável para conceituar e definir qual a filosofia deste grupo, uma vez que foi um movimento que durou mais de 1000 anos e contou com pensadores das mais diversos matizes do conhecimento, apesar de serem todos teólogos católicos. Com a pesquisa empreendida, torna- se compreensível o motivo de tantos historiadores da economia classificarem os escolásticos como fundadores desta ciência. Eram filósofos sofisticados em seu trabalho de aplicar análise moral a fatos cotidianos, muitos de natureza econômica, como a licitude de fazer comércio ou cobrar 
juros. Os escolásticos entenderam muito bem a importância da propriedade privada individual em detrimento da propriedade coletiva, antecipando o que viria, século depois, a ser chamada de "tragédia dos comuns". Permitiram formidável entendimento no que se refere a inflação e valor da moeda no tempo, deram o lastro necessário para ao desenvolvimento do mercado de câmbio e foram fundamentais, até mesmo para o desenvolvimento do conhecimento e ciência como conhecemos hoje, mérito das suas grandiosas universidades. A maior contribuição foi sua teoria subjetiva de valor, que contrapõe a teoria marxista do valor objetivo e mais-valia, tendo muito mais aderência com a realidade, no que tange a correta análise dos determinantes dos preços.

Por fim, afirma-se aqui o mérito e a importância do tema abordado. Não há como estudar a história da ciência econômica, ou mesmo olhar para seu futuro, sem ter em mente a monumental contribuição dos escolásticos. A análise se faz necessária à medida em que ajuda a desmistificar preconceitos com o medievo e confronta até mesmo, em alguns pontos, teorias consagradas. Como é o caso da Weberiana, sobre a importância da ética das religiões no progresso econômico, oferecendo uma visão, que ainda é minoritária, mas, sem dúvidas, relevante dentro do meio acadêmico. Algo que torna o debate acadêmico multidisciplinar, não se atendo apenas aos instrumentais matemáticos, uma vez que a ciência econômica, em última instância, estará sempre tratando de indivíduos humanos, com dilemas morais, raramente utilitaristas e isto, os escolásticos entenderam melhor do que qualquer outro grupo.

\section{Referências}

AMADO, Adriana Moreira. Limites monetários ao crescimento: Keynes e a não-neutralidade da moeda. Ensaios FEE, v. 21, n. 1, 2000.

ANTISERI, Dario; REALE, Giovani. História da filosofia: patrística e escolástica. São Paulo: Paulus, 2003.

ASSAF NETO, Alexandre. Mercado Financeiro. São Paulo: Atlas, 2003.

AZPILCUETA, Martin de. Commentary on the resolution of money. Journal of market and morality, v. 7, n. 1, 2004.

BARBOSA, Camilo de Lelis Colani; PAMPLONA FILHO, Rodolfo. Compreendendo os novos limites à propriedade: uma análise do Artigo 1.228 do Código Civil Brasileiro. Revista Magister de Direito Civil e Processual Civil, Porto Alegre, n. 9, 2004.

BOBBIO, Norberto. O positivismo jurídico: lições de filosofia do direito. São Paulo: Ícone, 1999.

CAMPOS, Roberto de Oliveira. Uma Interpretação Institucional das Leis Medievais da Usura. Revista Brasileira de Economia, Rio de Janeiro, v. 6, n. 2, 1952. Disponível em: http://bibliotecadigital.fgv.br/ojs/index.php/rbe/ article/view/2387. Acesso em: 12 out 2018.

CARCANHOTO, Reinaldo Antônio. O valor, a riqueza e a teoria de Smith. Análise Econômica, Porto Alegre, v. 1, n. $15, \operatorname{mar} / 1991$.

CARVALHO, Olavo Luiz Pimentel de. A escolástica: aula 15. São Paulo: É realizações, 2007.

CHAFUEN, Alejandro. Faith and Liberty: The Economic Thought of the Late Scholastics. Lanham, Md.: Lexington Books, 2003. 
COPLESTON, Frederick. A history of philosophy: Medieval philosophy. New York: Doubleday, 1950.

CUSTÓDIO, Sueli Sampaio Damin. A organização política no século XIV segundo o "Tratado sobre a moeda" de Nicolas Oresme. Kriterion, v. 131, 2015.

DEBONI, Giuliano. Propriedade privada: do caráter absoluto à função social e ambiental: sistemas jurídicos italiano e brasileiro. Porto Alegre: Verbo Jurídico, 2011.

FABRE, Raúl Gozález. Justicia em el mercado: La fundamentácion de la ética del mercado según Francisco de Vitória. Caracas: Publicaciones UCAB, 1998.

FEIJÓ, Ricardo. História do pensamento econômico. São Paulo: Atlas, 2001.

FRIEDMAN, Milton. Episódios da História Monetária. Rio de Janeiro: Record, 1992.

GARCIA, Manuel Enriquez.; VASCONCELLOS, Marco Antônio Sandoval de. Fundamentos de economia, São Paulo: Saraiva, 2004.

GRICE-HUTCHINSON, Marjorie. The school of Salamanca: readings in Spanish monetary theory, 1544-1605. Oxford: Orxford University Press, 1952.

GENNARI, Adilson Marques; OLIVEIRA, Roberson de. História do pensamento econômico. São Paulo: Saraiva, 2009.

GREGG, Samuel. Ethics and the Market economy: insights from Catholic moral theology. Economic Affairs, v. 24, n. 2, 2004.

HUERTA DE SOTO, Jesús. Juan de Mariana y los escolásticos españoles. Dendra Médica Revista de Humanidades, [s. 1.], v. 13, n. 1, 2013.

HUIZINGA, Johan. O declínio da idade média. Lisboa: Ulisséa, 1978.

IORIO, Ubiratan Jorge. Dos Protoaustrícos a Menger: Uma breve história das origens da escola austríaca de economia. São Paulo: LVM, 2017.

JONER, Henrique. A filosofia da economia e o monopólio na segunda escolástica. 2015. Dissertação (Mestrado em filosofia) - Unidade acadêmica de pesquisa e pós-graduação, Universidade do Vale do Rio dos Sinos, São Leopoldo, 2015.

LAURES, John. The political economy of Juan de Mariana. New York: Fordham University Press, 1928.

LE GOFF, Jacques. Os intelectuais da Idade Média. Rio de Janeiro: José Olympio, 2003.

LE GOFF, Jacques. A Idade Média e o dinheiro: Ensaio de uma antropologia histórica. Rio de Janeiro: Civilização Brasileira, 2014.

LOPES, Luiz Martins; VASCONCELLOS, Marco Antônio Sandoval de. Manual de macroeconomia: básico e intermediário. São Paulo: Atlas, 2008.

MACEDO, Paulo Emilio Vauthier Borges de. O mito de Francisco de Vitória: defensor dos direitos dos índios ou patriota espanhol?. Revista de Direito Internacional, v. 9, n. 1, 2012.

MANKIW, Nicholas Gregory. Principles of macroeconomics. Boston: Cengage Learning, 2012.

MARX, Karl. História crítica da teoria da mais-valia. 18 de Brumário. Buenos Aires: Clacso Libros, 1974.

MARX, Karl. O capital: crítica da economia política. O processo de produção do capital. São Paulo: Abril cultural, 1984. 
MATIAS-PEREIRA, José. Custos da escassez no meio circulante do Brasil de moedas metálicas. Observatório de la econômica latino-americana, n. 123, 2010. Disponível em: http://www.eumed.net/cursecon/ecolat/br/10/ jmp.htm. Acesso em: 23 out 2018.

MELLO, Leonel Itaussu Almeida. John Locke e o individualismo liberal. In: WEFFORT, Francisco Correia. Os clássicos da política. Santos: Ática, 2001.

MENGER, Carl. Liberalismo: Princípios da economia política. São Paulo: Lebooks, 2017.

MISES, Ludwig Heinrich Edler Von. Ação humana: um tratado de economia. São Paulo: Instituto Ludwig Von Mises Brasil, 2010.

MISES, Ludwig Heinrich Edler Von. Teoria e história: uma interpretação da evolução social e econômica. São Paulo: Instituto Ludwig Von Mises Brasil, 2014.

MOLLO, Maria de Lourdes Rollemberg. A questão da complementariedade das funções da moeda: aspectos teóricos e a realidade das hiper-inflações. Ensaios FEE, v. 14, 1993.

OLIVEIRA, Gilson Batista de; SCOVILLE, Eduardo Henrique Martins López de. As contribuições e o pensamento de John Stuart Mill no campo de economia. Revista FAE, Curitiba, v. 17, n. 1, 2014.

PEREIRA, Gonçalo Baldaque Marinho Camposo. Responsabilidade Civil Médicos - Fatores de Risco. 2013. Dissertação (Mestrado em gestão) - Faculdade de Economia e Gestão - Universidade Católica Portuguesa, Cidade do Porto, 2013.

PIMENTEL, Manoel Pedro. Crime de usura. Conferência de direito penal da Faculdade de Direito da Universidade de São Paulo. São Paulo. Conferências, 1974.

PONDÉ, J. L. Nova Economia Institucional. Rio de Janeiro: Fundação Getulio Vargas, 2007.

ROCHA, Márcio Mendes. Mobilidade forçada - a economia política dos deslocamentos humanos. Acta Scientiarum, v. 21, 1999.

ROBBINS, Lionel. An essay on the nature and significance of economic science. London: Macmillan and co., 1932.

ROBBINS, Lionel. A history of economic thought. New Jersey: Princeton University Press, 1998.

RODRIGUES, Domingos de Gouveia. Introdução à história do pensamento econômico (teoria econômica). Joinville: Clube dos autores, 2015.

ROOVER, Raymond de. Scholastic Economics: Survival and Lasting Influence from the Sixteenth Century to Adam Smith. The Quarterly Journal of Economics, v. 69, n. 2, 1955. Disponível em: https://www.jstor.org/ stable/1882146. Acesso em: 14 out 2018.

ROTHBARD, Murray Newton. Economic thought before Adam Smith: An Austrian perspective on the history of economic thought. Aubum: Edward Elgar Publishing, 1995.

SABINE, George Hollan. Historia de la teoria politica. Ciudad de México: Fondo de cultura económica, 1945.

SÁNCHEZ-SERNA, Aracely del Socorro.; ARIAS BELLO, Martha Liliana. Concepción de valor y precio desde Aristóteles a los clásicos: una reflexión a la luz de las premisas de valoración de las Normas Internacionales de Información Financiera, NIIF. Cuadernos de Contabilidad, v. 13, n. 33, 2012. Disponível em: http://revistas. javeriana.edu.co/index.php/cuacont/article/view/4261. Acesso em: 12 out 2018.

SCHUMPETER, Joseph Alois. History of economic analysis. London: Allen \& Unwin Publishers, 1954. 
SOARES, Ricardo Maurício Feire. Reflexões sobre o jusnaturalismo: O direito natural como direito justo. Revista do Curso de Direito da UNIFACS, Salvador, v. 7, 2008.

THORTON, Mark. Cantillon on the cause of bussines cycle. The Quaterly Journal of Austrian Economics, v. 9, n. 3, 2006.

VENOSA, Sílvio de Salvo. Direito Civil - Direitos reais. São Paulo: 1999.

VIEJO-XIMÉNEZ, José Miguel. Totus orbis, qui aliquo modo est uma república: Francisco de Vitoria, el derececho de genres y la expansión atlântica castellana. Revista de Estúdio Histórico-Jurícos, Valparaiso, n. 26, Sección História del Pensamiento Jurídico, 2004.

WOODS Jr., Thomas Ernest. How the catholic church built western civlization. Washington: Regnery Publishing, 2005.

RECEBIDO EM: 11/12/2018

APRovado EM: 17/04/2019 